\title{
Sedimentology and stratigraphy of the type section of the Pennsylvanian Boss Point Formation, Joggins Fossil Cliffs, Nova Scotia, Canada
}

\author{
Michael C. Rygel ${ }^{1 *}$, Corinne Lally ${ }^{1}$, Martin R. Gibling ${ }^{2}$, Alessandro Ielpi ${ }^{2}$, \\ John H. CALDER ${ }^{3}$, ANd ARden R. Bashforth ${ }^{4}$
}

\author{
1. Department of Geology, State University of New York, College at Potsdam, 44 Pierrepont Ave., \\ Potsdam, New York 13676, USA \\ 2. Department of Earth Sciences, Dalhousie University, Halifax, Nova Scotia B3H 4R2, Canada \\ 3. Nova Scotia Department of Natural Resources, P.O. Box 698, Halifax, Nova Scotia B3J 2T9, Canada \\ 4. Department of Paleobiology, National Museum of Natural History, Smithsonian Institution, \\ Washington, District of Columbia 20560, USA \\ *Corresponding author <rygelmc@potsdam.edu $>$
}

Date received: 23 February 2014 Date accepted: 20 July 2014

\begin{abstract}
The 1125-m-thick type section of the Pennsylvanian Boss Point Formation is well exposed along the shore of the Bay of Fundy in Nova Scotia. We provide the first comprehensive account of the entirety of this formation, which comprises nearly one-third of the stratigraphic thickness of the Joggins Fossil Cliffs UNESCO World Heritage Site. The basal Chignecto Bay Member $(0-91.5 \mathrm{~m})$ is composed of redbeds, single-storey channel bodies with northerly paleoflow, and thin palustrine limestones. The middle Ward Point Member (91.5-951.7 m) contains up to 16 megacycles composed of alternations between thick packages of braided fluvial sandstone and fine-grained deposits. Although regional studies of the Boss Point Formation suggest that the fine-grained deposits are largely composed of lacustrine sediments, these intervals consist largely of poorly drained and well-drained floodplain deposits in the type section. The facies variations and southeast-directed paleoflow in the Ward Point Member record modest uplift associated with the growth of the salt-cored Minudie Anticline. The North Reef Member (951.7-1125 m) is composed of redbeds and two distinctive multistorey channel bodies. This uppermost member records a shift to more arid, oxidizing conditions, was the precursor to a major phase of salt withdrawal, and represents a transition to the overlying Little River Formation. The sedimentological framework, revised stratigraphy, and detailed measured section and map will provide a foundation for future study of this remarkable Pennsylvanian exposure.
\end{abstract}

\section{RÉSUMÉ}

Le stratotype de 1125 mètres dépaisseur de la formation de Boss Point du Pennsylvanien est bien exposé sur la rive de la baie de Fundy, en Nouvelle-Écosse. Nous présentons le premier compte rendu complet de cette formation dans son intégralité, qui comprend près du tiers de l'épaisseur stratigraphique des falaises fossilifères de Joggins, reconnues site du patrimoine mondial de l'UNESCO. Le membre basal de la baie Chignectou (de $0 \mathrm{~m}$ à $91,5 \mathrm{~m}$ ) se compose de couches rouges, de corps de chenaux monostratifiés au paléo-écoulement vers le nord et de minces 
couches de calcaire palustre. Le membre moyen de Ward Point (de 91,5 m à 951,7 m) renferme jusqu'à 16 mégacycles composés en alternance d'épaisses masses de grès fluvial anastomosé et de dépôts à grains fins. Même si des études sur la région de la formation de Boss Point donnent à penser que les dépôts à grains fins sont surtout composés de sédiments lacustres, ces intervalles sont constitués en grande partie de dépôts alluviaux mal drainés et bien drainés dans le stratotype. Les variations dans le faciès et le paléo-écoulement en direction du sud-est dans le membre de Ward Point témoignent d'un soulèvement modeste associé à la croissance de l'anticlinal de Minudie à noyau salifère. Le membre de North Reef (de 951,7 m à $1125 \mathrm{~m}$ ) se compose de couches rouges et de deux corps de chenaux multistratifiés distinctifs. Ce membre supérieur atteste d'une transition vers des conditions oxydantes, plus arides, il a été le précurseur d'une importante phase de retrait du sel et il représente une transition vers la formation sus-jacente de Little River. Le cadre sédimentologique, la stratigraphie révisée ainsi que la coupe et la carte détaillées mesurées serviront de fondement à une prochaine étude sur ce remarquable affleurement de la période pennsylvanienne.

[Traduit par la redaction]

\section{INTRODUCTION}

The 1125-m-thick type section of the Boss Point Formation comprises approximately one third of the stratigraphic thickness of the Joggins Fossil Cliffs UNESCO World Heritage Site. It is of earliest Pennsylvanian age (Fig. 1 ) and is almost continuously exposed in a $2.5-\mathrm{km}$-long coastal section near the northern limit of the protected zone (Figs. 2, 3). It was deposited in the Cumberland Basin, part of the larger Maritimes Basin of Atlantic Canada (Ryan and Boehner 1994; Calder 1998; Gibling et al. 2008). The Formation has been examined on a regional scale (Browne and Plint 1994; Plint and Browne 1994; Ryan and Boehner 1994; St. Peter and Johnson 2009), but the entirety of the type section has not previously been described in detail.

Although the Boss Point Formation largely lacks the fossil forests that are ubiquitous in overlying strata, it records an equally diverse spectrum of environments, including rivers, floodplains, lakes, and rare peat-forming mires. It was deposited in association with a shift from arid to sub-humid climate in the aftermath of the mid-Carboniferous event (Calder 1998; Allen et al. 2011), and the fossils record both dryland cordaitalean-dominated forests (Ielpi et al. 2014) and some of the earliest incarnations of the coal-swamp ecosystem that would eventually become widespread in humid, paleoequatorial regions of Pangea.

Regional studies suggest that the middle part of the Boss Point Formation contains 16 megacycles (Figs. 4, 5) that can be correlated across much of the Cumberland Basin (Browne and Plint 1994). Megacycles are composed of

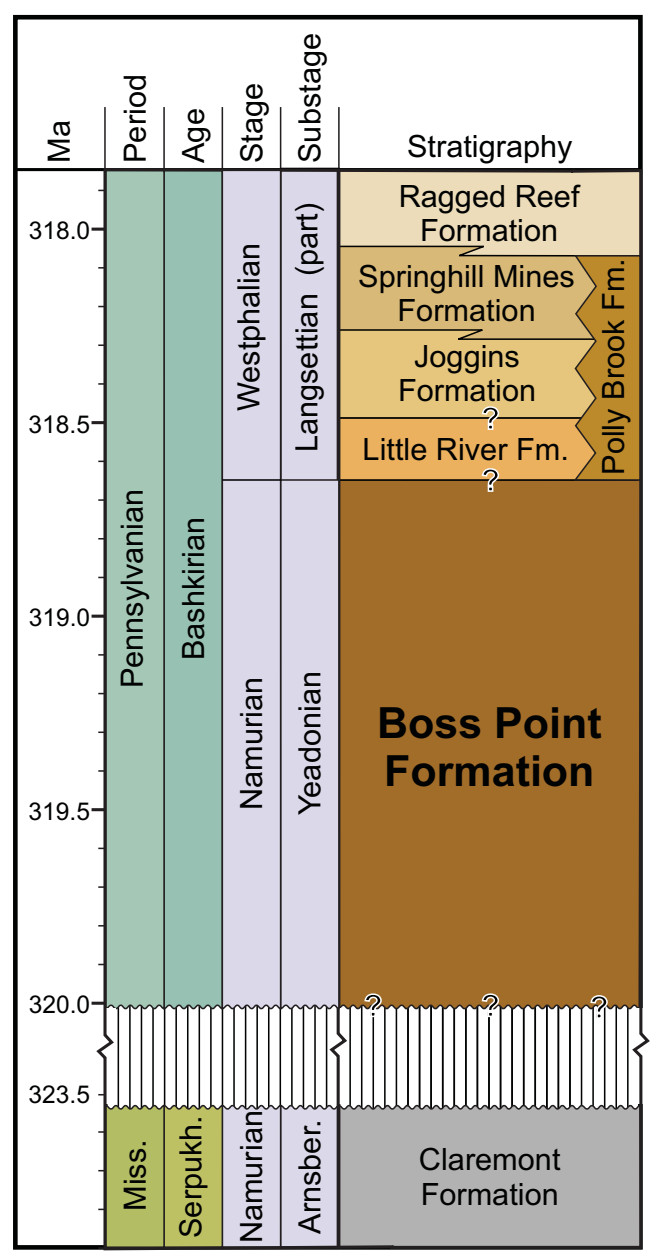

Figure 1. Age and stratigraphic relationships of many of the units exposed in the Joggins Fossil Cliffs UNESCO World Heritage Site. All the Pennsylvanian units are part of the Cumberland Group; the Claremont Formation is the uppermost unit in the Mabou Group (see Fig. 2). Modified after Ryan et al. (1991), St. Peter and Johnson (2009), and Utting et al. (2010). Please note that the depiction of stratigraphic units relative to named subdivisions of time are from Utting et al. (2010, fig. 14) and that placements are only approximate. In particular, placement of the Yeadonian-Langsettian boundary and maximum age of the Boss Point are speculative because the Boss Point and Little River formations cannot be assigned an age more specific than late Yeadonian-Langsettian (Utting et al. 2010). Numeric dates derived from TS Creator (v. 6.2; https://engineering.purdue.edu/Stratigraphy/tscreator/index/index.php), which uses an updated version of the data from Gradstein et al. (2012). Abbreviations are for Mississippian (Miss.), Serpukhovian (Serpukh.), and Arnsbergian (Arnsber.). 


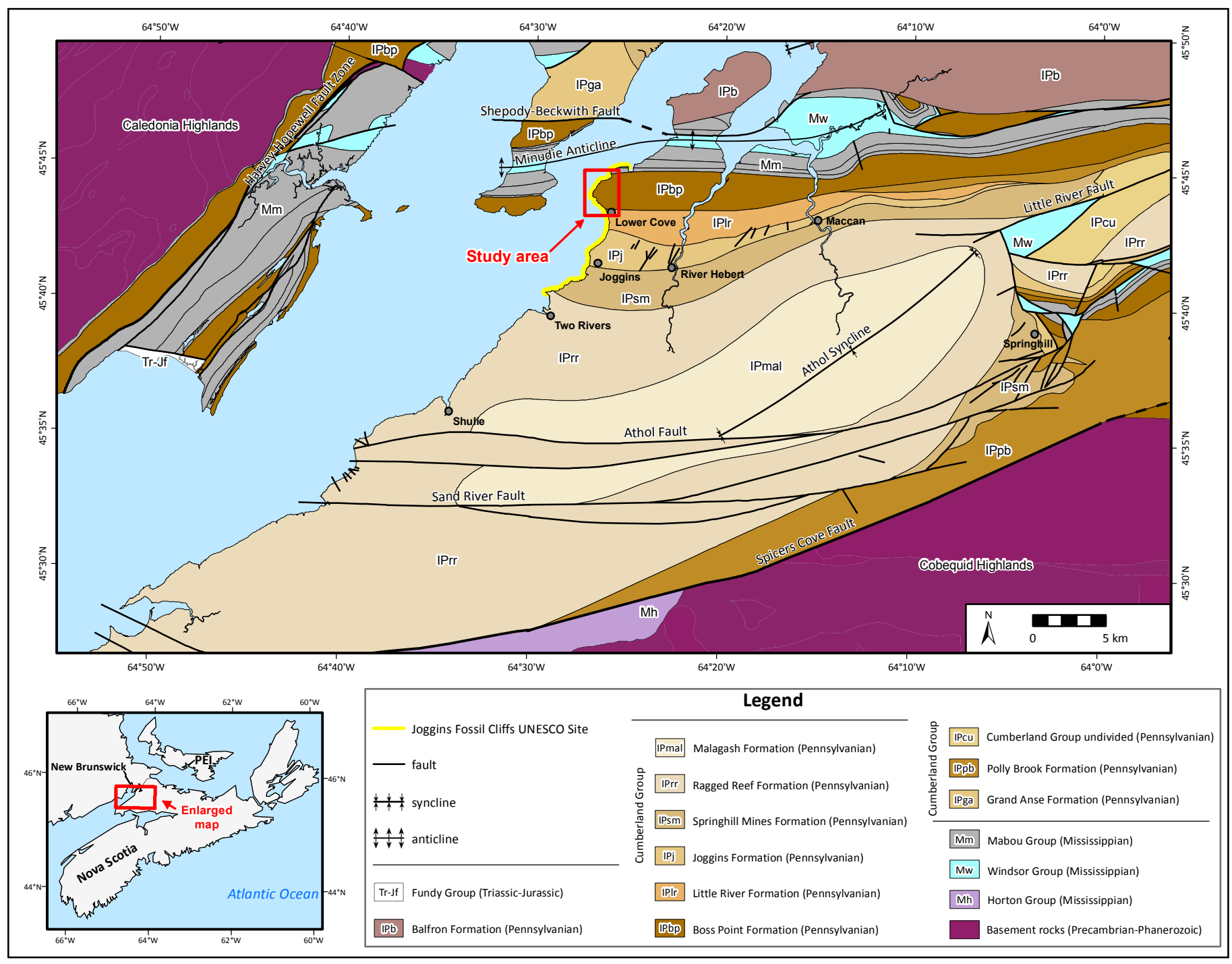

Figure 2. Geologic map of the western Cumberland Basin showing the study area along the coast, the partial distribution of the Boss Point Formation, and the extent of the Joggins Fossil Cliffs UNESCO World Heritage Site. Modified from Ryan et al. (1990a; 1990b), New Brunswick Department of Natural Resources and Energy (2000), and Keppie (2006).

thick packages of braided fluvial sandstones that are sharply overlain by thinner packages of "lacustrine" sediments that accumulated following episodic downdrop of the basin floor (Browne and Plint 1994; Plint and Browne 1994). However, recent work at the type section (Gardiner 2005; Ielpi et al. 2014) indicates that there are local sedimentological differences that, at least initially, cannot be easily reconciled with the braided fluvial-lacustrine model.

This paper is the fourth in a series that provides a sedimentological framework for the units in the Joggins Fossil Cliffs UNESCO World Heritage Site, following earlier papers by Calder et al. (2005), Davies et al. (2005) and Rygel et al. (2014). Herein, we provide the justification and description of this unit (Appendix 1), a detailed measured section (Appendix 2), map of the coastal outcrop, facies descriptions and interpretations that we hope will serve as a foundation for future studies of this world-class exposure.

\section{GEOLOGIC SETTING}

\section{Regional stratigraphy and tectonics}

The Boss Point Formation and correlative units formed as a sand-rich blanket of sediment that covered much of the Maritimes Basin following the Mississippian-Pennsylvanian unconformity and the onset of Alleghanian tectonism (Rehill 1996; Calder 1998; Gibling et al. 2008). Equivalent units are 


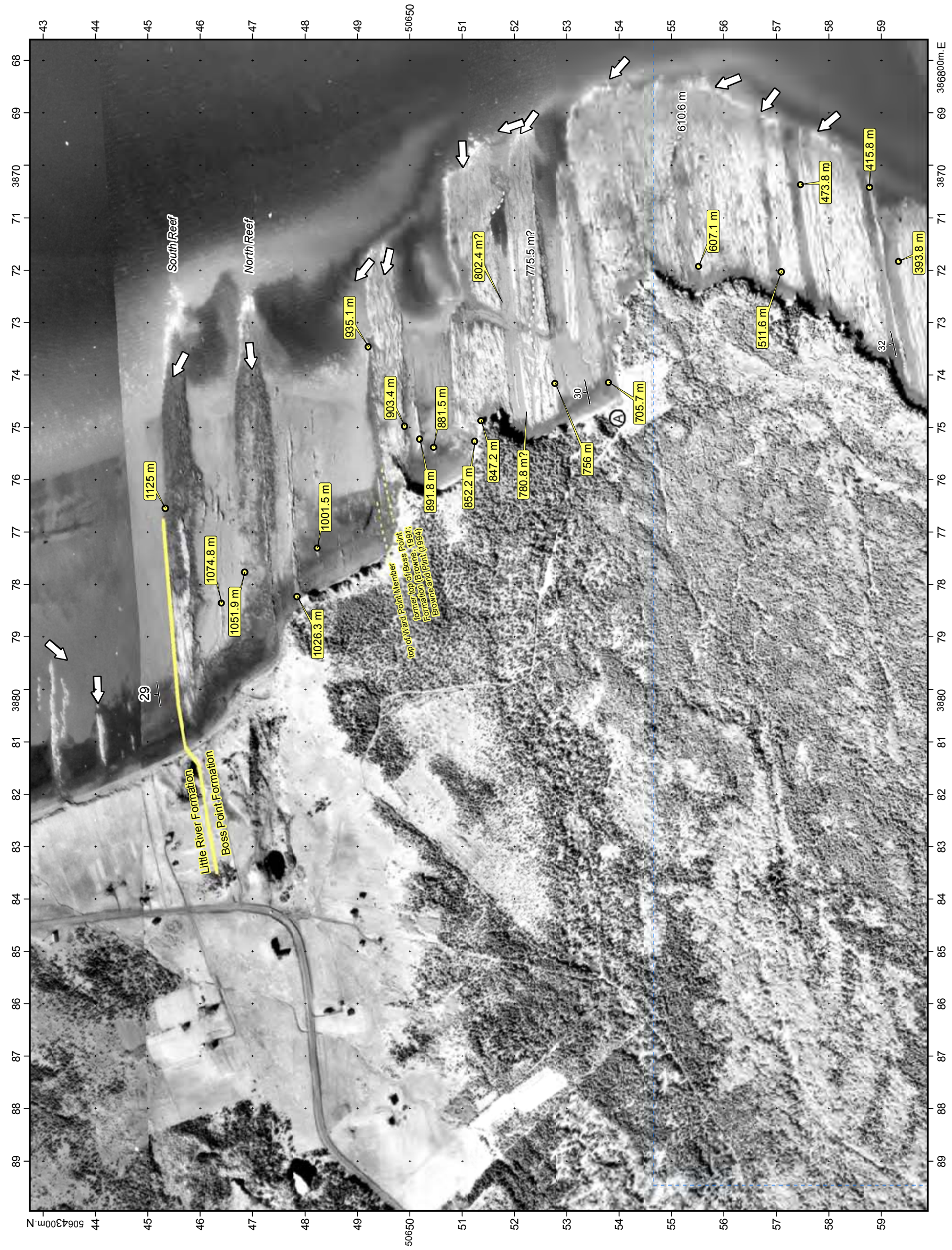




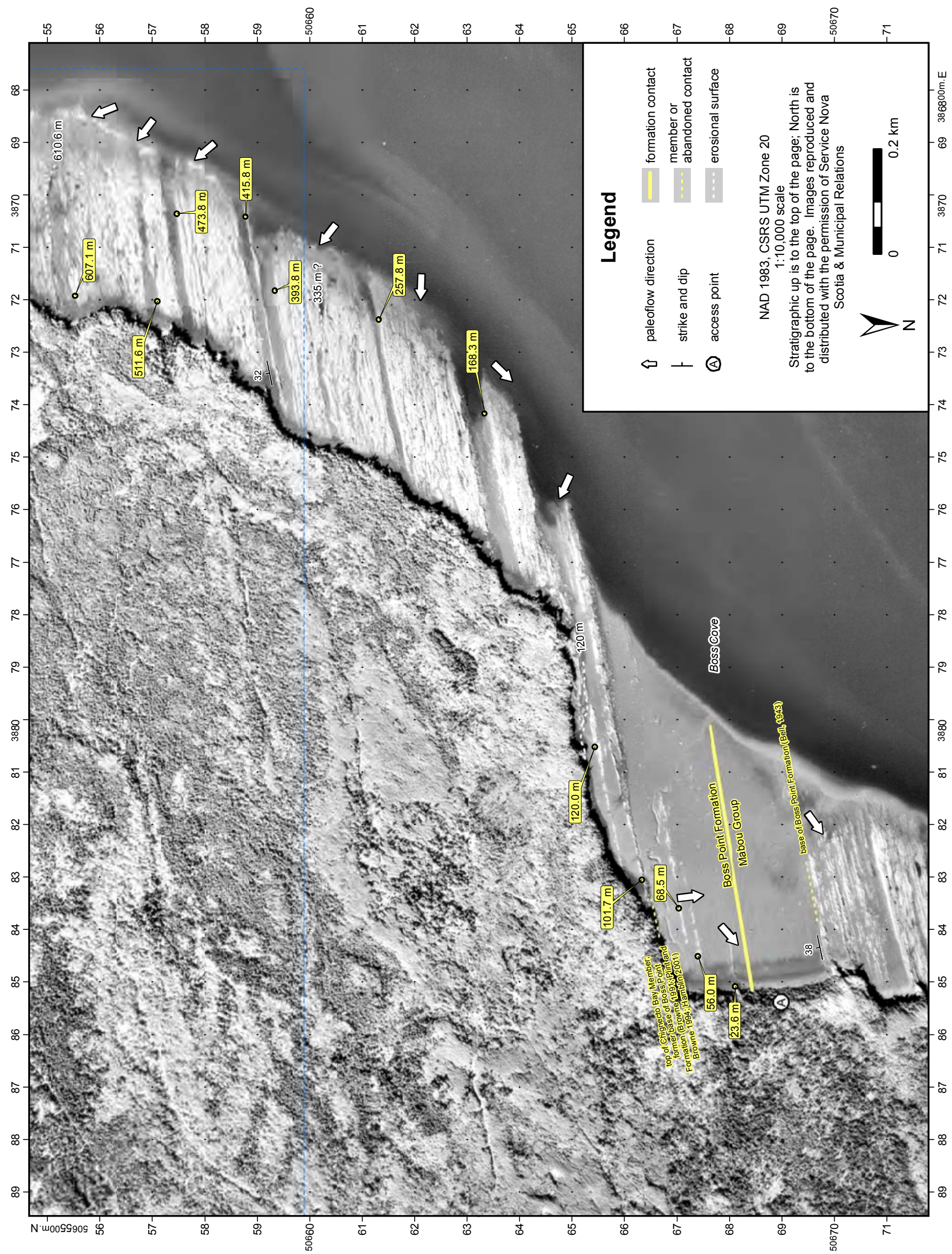


Figures 3a, 3b. (previous two pages) 1:10 000-scale map showing the coastal exposure of the Boss Point Formation (see box in Fig. 2). The background image is a photomosaic constructed from airphotos showing the intertidal zone at low tide. Prominent outcrops in the intertidal zone are labeled to indicate stratigraphic position in the measured section. Note that the map is oriented so that stratigraphic up is to the top of the map and north is to the bottom of the map. Placement of the basal contact of the Boss Point Formation differs from its location in Ryan et al. (1990b), who incorrectly show it at the north end of Boss Cove at the base of a covered interval at the top of Logan's Division 7 (Bell 1943 intentionally placed it at this location). Dashed blue lines are extent rectangles that show the area of overlap between the two panels. Airphotos were georeferenced using basemap images provided by the Environmental Systems Research Institute (ESRI). This map was produced by the authors and includes data that was reproduced with the permission of, and provided by Service Nova Scotia and Municipal Relations (airphoto numbers A18580-121 and A18580-125). The incorporation of data sourced from Service Nova Scotia and Municipal Relations within this product shall not be construed as constituting an endorsement by Service Nova Scotia and Municipal Relations of our map.

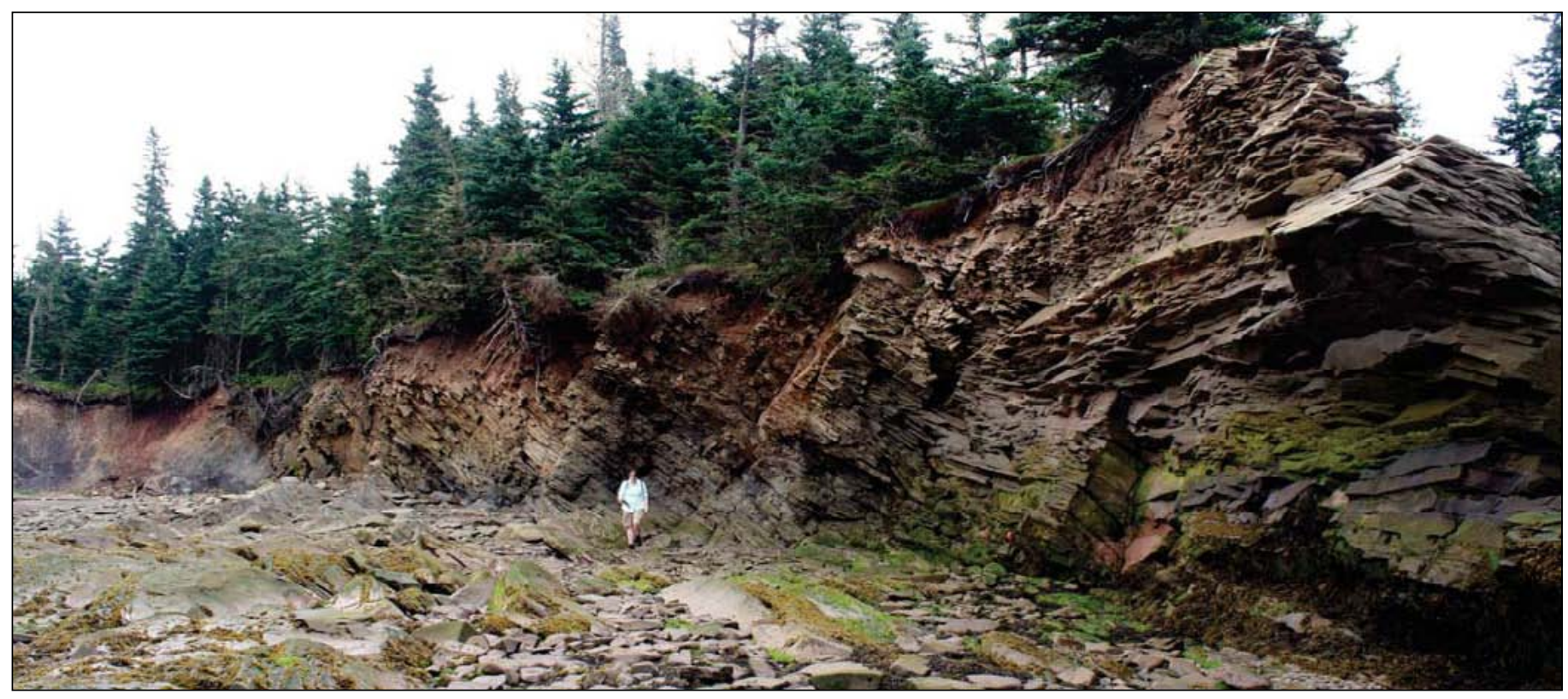

Figure 4. Transition from well-drained floodplain deposits (left) to multistorey channel bodies (right) at approximately 479-509 $\mathrm{m}$ in the Boss Point Formation, which represents the upper part of Browne and Plint's (1994) megacycle 6. Stratigraphic up is to the right. Cyclic alternations between fine-grained facies and fluvial sandstones are characteristic of the Ward Point Member of the Boss Point Formation (91.5-951.7 m) and many cycles can be traced regionally (Browne and Plint 1994; see Appendix 2 for a sedimentological log of this interval).

well exposed along the western coast of Cape Breton Island, but the thickest and best exposures occur in the Cumberland Basin of Nova Scotia and New Brunswick, exposed along the shores of Chignecto Bay, the inner, northern arm of the Bay of Fundy (Fig. 2; Ryan and Boehner 1994; St. Peter and Johnson 2009).

The Cumberland Basin is situated largely between the crystalline rocks of the Caledonia and Cobequid highlands (Fig. 3). It contains an 8-km-thick package of Devonian through earliest Permian strata that includes the Horton, Windsor, Mabou, Cumberland, and Pictou groups (Gibling et al. 2008). The Boss Point Formation is the oldest unit in the Pennsylvanian (Bashkirian) Cumberland Group; it is overlain by the Little River, Joggins, Springhill Mines, and Ragged Reef formations (Fig. 1). The basin is bounded by the Harvey-Hopewell, Spicer's Cove, Hastings, and CaledoniaDorchester faults, which have a complex history that likely includes both dip-slip and strike-slip motion (Webb 1963; Browne and Plint 1994). These faults are part of a regional network that facilitated $\sim 250 \mathrm{~km}$ of dextral transpression in the late Paleozoic (Nance 1987; Hibbard and Waldron 2009).

Recent studies of subsurface seismic profiles reveal that the stratigraphic architecture of the Cumberland Basin was profoundly influenced by salt tectonism associated with the underlying evaporites of the Mississippian Windsor Group (Waldron and Rygel 2005; Waldron et al. 2013). The study 


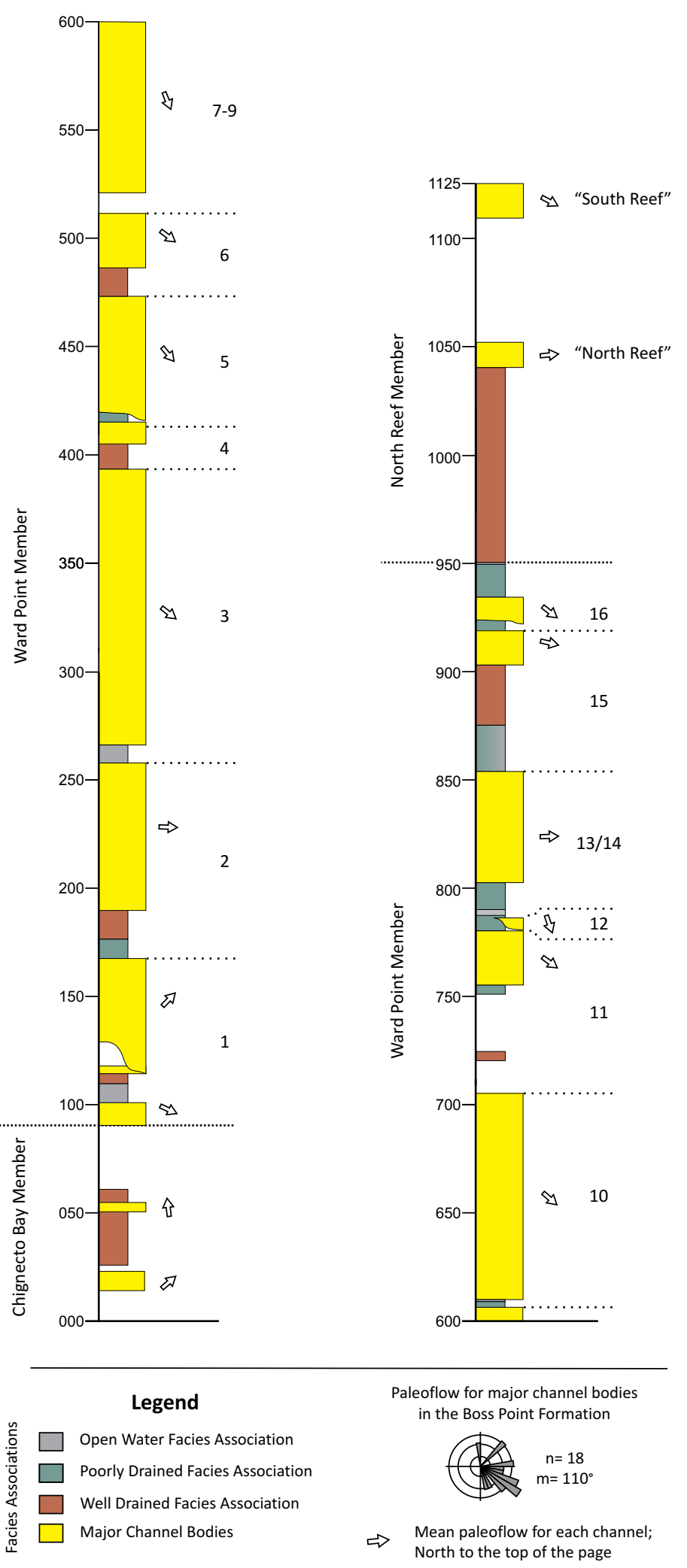

Figure 5. Summary section derived from Appendix 2 showing facies associations, paleoflow direction, correlations with formal and informal members proposed by Ryan et al. (1991) and St. Peter and Johnson (2009), and Plint and Browne's (1994) megacycles (numbered). area is in the western part of the Cumberland Basin where the Mabou Group is of uniform thickness and has reflectors that are concordant with overlying Pennsylvanian strata, suggesting that major salt withdrawal did not begin until the Pennsylvanian (Waldron et al. 2013). The Boss Point Formation is a roughly kilometre-thick package of sandrich sediment that was delivered by through-going trunk rivers sourced in the rising Appalachians (Gibling et al. 1992; Browne and Plint 1994). The wide distribution and relatively constant thickness of the Boss Point Formation suggests that it did not cause significant differential loading and was deposited during a time of modest passive diapirism (Waldron et al. 2013). Plint and Browne (1994) interpreted the braided fluvial-lacustrine megacycles as a consequence of episodic downdrop associated with motion along basin-bounding faults (Fig. 4). Seismic data indicate that the most significant phase of salt withdrawal in the western Cumberland Basin took place during deposition of the overlying Little River, Joggins, and Springhill Mines formations in the Athol Syncline minibasin (Waldron and Rygel 2005).

\section{Stratigraphy of the type section}

The Joggins section includes $\sim 4500$ m of continuously exposed Mississippian and Pennsylvanian strata along the southern shore of Chignecto Bay. The designated World Heritage Site is the $\sim 3500-\mathrm{m}$-thick interval exposed between Downing Head and Ragged Reef Point (Fig. 2). The 1125-m-thick type section of the Boss Point Formation crops out in a 2.5-km-long coastal exposure between Boss Cove and South Reef (Fig. 3). These strata occur on the shared limb of the Minudie Anticline (to the north) and the Athol Syncline (to the south) and dip systematically to the south at $20-35^{\circ}$.

Strata of the Joggins section were originally described by William Logan in June, 1843 (Logan 1845; Rygel and Shipley 2005). As currently defined (Fig. 6), the Boss Point Formation corresponds exactly to Logan's Division 6, which was originally estimated to contain 3240 feet 9 inches ( 987.8 $\mathrm{m}$ ) of sandstone, red and grey mudrock, thin limestones, and a few thin coals. The contact with the underlying redbeds and conglomerates of Division 7 (Claremont Formation) is at the base of a thin limestone exposed near the centre of Boss Cove; the contact with the relatively fine-grained redbeds of Division 5 (Little River Formation) occurs at the top of South Reef, the uppermost of the thick intertidal sandstones (Fig. 3).

Bell (1914) introduced the term "Boss Point Formation" to describe the beds in Logan's Divisions 6 and 7. He later restricted the definition to include all of Division 6 and 282 feet 6 inches $(86.1 \mathrm{~m})$ of largely concealed section at the top of Division 7 (Bell 1943). This definition remained largely unchanged through decades of mapping and scrutiny (Copeland 1959; Belt 1964; Kelley 1967; Howie and Barss 1975). 


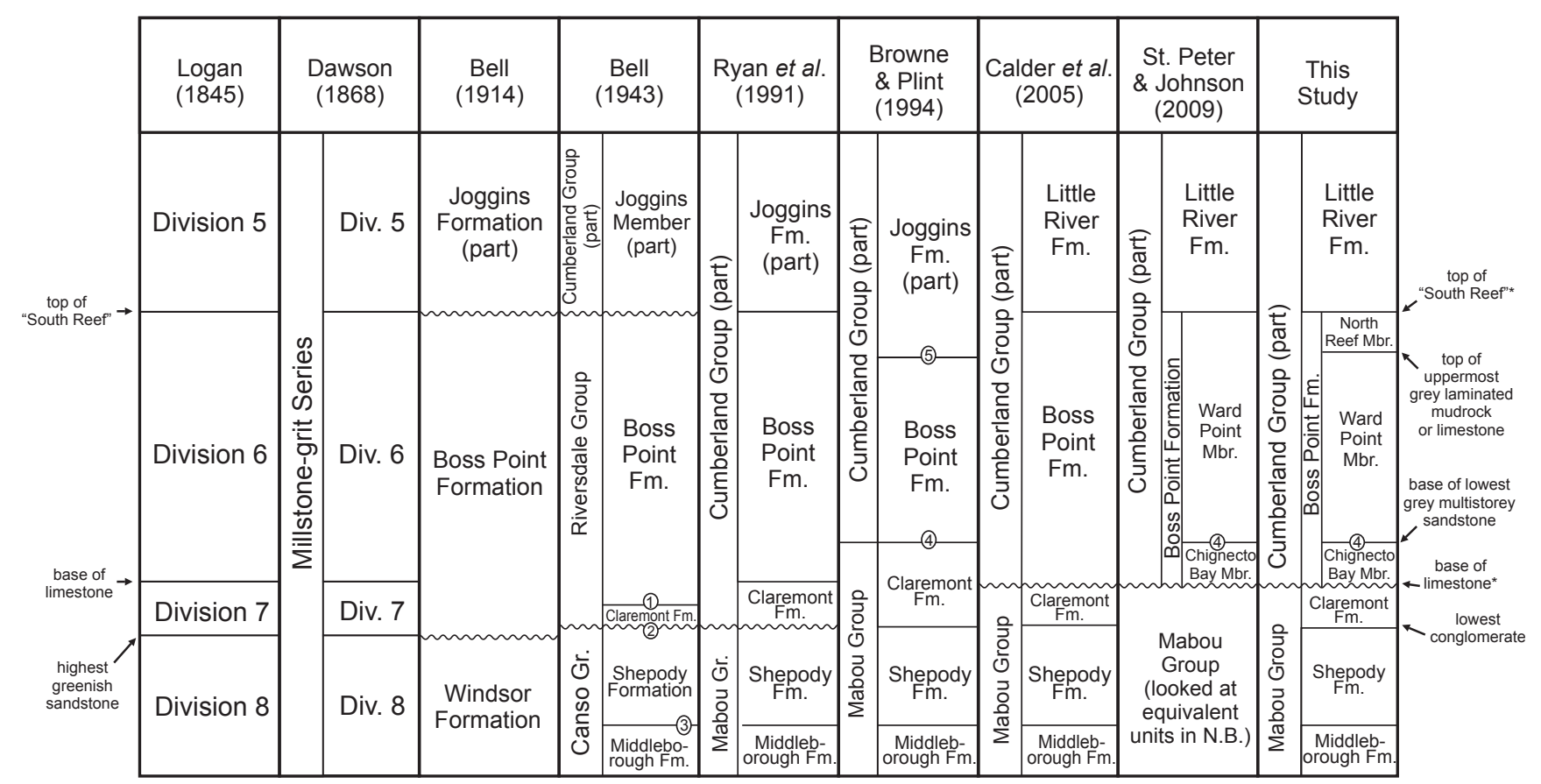

Figure 6. Major changes to the stratigraphic nomenclature applied to the section along Chignecto Bay. Circled numbers correspond to the following surfaces: (1) base of covered interval, (2) base of lowest conglomerate, (3) base of lowest grey sandstone, (4) base of lowest grey, multistorey channel body, and (5) top of uppermost erosion-dominated, multistorey channel body. Asterisks denote a modern boundary that corresponds to one of Logan's Division boundaries. Modified from Rygel and Shipley (2005).

Ryan et al. (1991) revised the definition of the Boss Point Formation to include the upper and lower redbeds so that it once again coincided with Logan's (1845) Division 6. Although never formally defined, the redbeds and distinctive channel bodies near the top of the formation (above $951.7 \mathrm{~m}$ in our section) were identified as the "North Reef member" in their figures and diagrams (Table 1). The redbeds and distinctive cross-bedded channel bodies in this interval mark the transition to the overlying Little River Formation (Calder et al. 2005) and feature prominently in Fielding et al. (2011).

St. Peter and Johnson (2009) formally defined the base of the Boss Point Formation as the base of the Pennsylvanian Cumberland Group because it represents a fundamental lithostratigraphic change. The contact represents an angular unconformity in the subsurface (Waldron and Rygel 2005) and records a pronounced biostratigraphic break marked by the appearance of Cordaites macroflora and the incoming of the cordaitalean prepollen Florinites (Calder 1998; Utting and Wagner 2005; Utting et al. 2010).

We recognize two previously defined members and one new one in the type section of the Boss Point Formation (Table 1). The two existing members are the redbeddominated Chignecto Bay Member (0-91.5 m in our section) and braided fluvial and "lacustrine" strata of the Ward Point Member (91.5-951.7 $\mathrm{m}$ in our section) of St. Peter and
Johnson (2009). We also formally define and describe the redbed-dominated North Reef Member (951.7-1125 m in our section). This unit was informally suggested by Ryan et al. (1991); the justification and description of this unit is provided in Appendix 1. The stratigraphic nomenclature used in this paper both follows the seminal work of Logan (1845) and Ryan et al. (1991) and acknowledges the sedimentological variation that prompted Browne (1991), Plint and Browne (1994), Browne and Plint (1994), and Hamblin (2001) to exclude the redbed-dominated intervals (Chignecto Bay and North Reef members) from their definition of the Boss Point Formation.

\section{Age}

The Boss Point Formation has been assigned a late Namurian to Langsettian age (Ryan et al. 1991; St. Peter and Johnson 2009). In older literature, macrofloral studies suggested a Langsettian age (Bell 1943; Utting and Wagner 2005) and palynostratigraphic studies favored a late Namurian age (Dolby 1991, 1994; Giles and Utting 1999).

Utting etal.(2010)conducteddetailedpalynostratigraphic studies of the entirety of the Joggins section. They assigned the Boss Point and Little River formations to the Raistrickia saetosa Assemblage Zone (Yeadonian to early Langsettian) and the overlying Joggins, Springhill Mines, and lower 
Table 1. Internal stratigraphy of the Boss Point Formation at the type section.

\begin{tabular}{|c|c|c|c|c|c|}
\hline Member name & $\begin{array}{l}\text { Interpreted position } \\
\text { in the type section }\end{array}$ & Status and author & Type and reference sections & Distribution & Description \\
\hline North Reef Member & $951.7-1,125 \mathrm{~m}$ & $\begin{array}{l}\text { Informal member shown in } \\
\text { diagrams of Ryan et al. (1991) and } \\
\text { formally defined in this paper. }\end{array}$ & $\begin{array}{l}\text { Type section is in the Joggins Section near } \\
\text { Lower Cove, Nova Scotia. }\end{array}$ & $\begin{array}{l}\text { Type section only; not yet mapped } \\
\text { or described from other locations. }\end{array}$ & $\begin{array}{l}\text { Redbed-dominated interval with the distinctive North Reef } \\
\text { and South Reef channel bodies. Upper contact placed atop } \\
\text { the highest multisotrey channel body in the section. }\end{array}$ \\
\hline Ward Point Member & $91.5-951.7 \mathrm{~m}$ & $\begin{array}{l}\text { Formal member defined by St. Peter } \\
\text { and Johnson (2009) }\end{array}$ & $\begin{array}{l}\text { Type section is on the Maringouin } \\
\text { Peninsula (New Brunswick) from Ward } \\
\text { Point to the Lower Rockport area. }\end{array}$ & $\begin{array}{l}\text { Restricted to the Cumberland Basin. } \\
\text { The type section was the only Nova } \\
\text { Scotia location described in their } \\
\text { publication. }\end{array}$ & $\begin{array}{l}\text { Grey, multistorey channel bodies interbedded with variably } \\
\text { colored mudrocks, thin sandstones, carbonaceous } \\
\text { limestones, and thin coal seams. Upper contact placed atop } \\
\text { the highest open water deposits. }\end{array}$ \\
\hline $\begin{array}{l}\text { Chignecto Bay } \\
\text { Member }\end{array}$ & $0-91.5 \mathrm{~m}$ & $\begin{array}{l}\text { Formal member defined by St. Peter } \\
\text { and Johnson (2009) }\end{array}$ & $\begin{array}{l}\text { Type section is on the east side of the } \\
\text { Maringouin Peninsula, New Brunswick. } \\
\text { Reference section on the west side of } \\
\text { Mary's Cove. }\end{array}$ & $\begin{array}{l}\text { Restricted to the Cumberland Basin. } \\
\text { The type section was the only Nova } \\
\text { Scotia location described in their } \\
\text { publication. }\end{array}$ & $\begin{array}{l}\text { Red to reddish gray mudrocks with very fine- to medium } \\
\text { grained sandstone. Upper contact placed at the base of the } \\
\text { lowest multistorey channel body. }\end{array}$ \\
\hline
\end{tabular}

Ragged Reef formations to the Raistrickia fulva Assemblage Zone (Langsettian). A Langsettian age for strata overlying the Boss Point Formation is consistent with recent macrofloral studies (Álvarez-Vázquez and Wagner 2014). Although magnetic polarity studies suggest a Langsettian age for the Boss Point Formation in the Cumberland Basin and a Yeadonian to Langsettian age in the New Glasgow area, these correlations are challenging and a sampling gap spans much of the Ward Point Member at the type section (DiVenere and Opdyke 1991; Opdyke et al. 2014).

In this paper we use the named age assignments as provided by Utting et al. (2010; their fig. 14) and numeric ages from TS Creator (v. 6.2; https://engineering.purdue. edu/Stratigraphy/tscreator/index/index.php), a database that contains an updated version of the timescale of Gradstein et al. (2012). It should be noted that the placement of the Yeadonian-Langsettian boundary is not well defined by palynology, and it is unclear how much of the time represented by these substages is actually recorded in the Boss Point Formation. Our age determination for the Boss Point Formation (Fig. 1) follows that of Utting et al. (2010) and places the top of the Boss Point Formation at the top of the Yeadonian and assumes that the whole Yeadonian interval is represented by the Boss Point Formation (thus the maximum age range). Consequently, the Boss Point Formation is shown as representing considerably more time than in other recent publications on the Cumberland Group (Allen et al. 2013; Waldron et al. 2013). Although the apparent longevity of Boss Point deposition is partially due to the uncertainty over its age, it could also reflect negligible halokinesis (Waldron et al. 2013) and/or relatively slow floodplain sedimentation during deposition of the formation.

\section{FACIES ASSOCIATIONS}

The detailed measured section provided in Appendix 2 is the reference for the sedimentological descriptions and interpretations provided below and the simplified portrayal of the Boss Point Formation shown in Fig. 5. The detailed measured section was compiled by direct measurement of beds exposed in the cliffs and use of a Jacob's staff and laser rangefinder for covered intervals. Covered intervals total $158.4 \mathrm{~m}$, or $15 \%$, of the formation thickness. Units were measured to the nearest $0.01 \mathrm{~m}$ in the field; thicknesses for clastic beds are generally reported to the nearest $0.1 \mathrm{~m}$ and thicknesses for organic-rich intervals to the nearest $0.01 \mathrm{~m}$.

Facies are described using the terminology developed for the overlying Joggins Formation (Davies and Gibling 2003). Although considerable differences exist in the constituent lithofacies, modification of the existing nomenclature makes for the most straightforward description and comparison of units within the Cumberland Group.

Our $1125 \mathrm{~m}$ thickness for the Boss Point Formation accords well with Logan's (1845) estimate of $987.8 \mathrm{~m}$, which was calculated from paced values collected over a 1.5-day traverse (Rygel and Shipley 2005). It is very close to Bell's (1943) value of $1087.9 \mathrm{~m}$ (he reported $1174 \mathrm{~m}$, from which we subtracted $86.1 \mathrm{~m}$ to compensate for the covered interval at the top of Division 7) and the $1075 \mathrm{~m}$ value reported by St. Peter and Johnson (2009), who partially drew upon Logan's measurements.

\section{Major channel bodies (CB)}

Channel bodies are identified by the metreage value at the top of the body; stratigraphic position is used to link the measured section (Fig. 5 and Appendix 2) to the map of the intertidal zone (Fig. 3). Paleoflow data were collected from each channel body, and an average paleoflow direction was calculated using the most reliable indicators. Reported values for channel body widths and width:thickness (W:T) values are corrected for paleoflow obliquity relative to the outcrop orientation. We use terminology from Gibling (2006) for geometry, Holbrook (2001) for bounding surfaces, and Miall (1996) for lithofacies and macroforms.

Eighteen major channel bodies (those greater than $4 \mathrm{~m}$ thick) were described from the accessible portion of the coastal exposure (Fig. 5; Appendix 2). They have a 

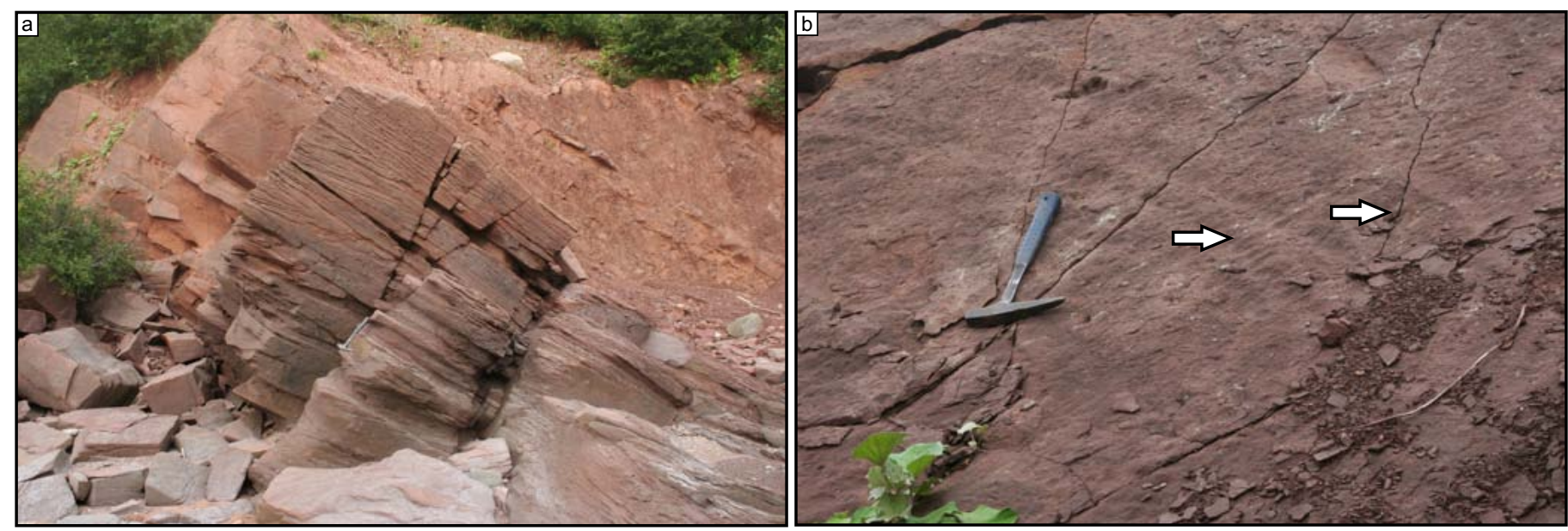

Figure 7. Lower redbed channel body at $46.5 \mathrm{~m}$ in the Chignecto Bay Member. (a) Cross-sectional view of the channel body showing stacked sets of cross-beds capped with a ripple cross-laminated interval. Both lower redbed channel bodies have this type of simple cut-and-fill architecture. (b) Bedding plane view of Diplichnites cuithensis (trackway of a large arthropleurid) present atop the ripple cross-laminated interval at the top of the channel body. Hammer is $32 \mathrm{~cm} l o n g$.

cumulative thickness of $676.2 \mathrm{~m}$ and represent $60 \%$ of the thickness of the Boss Point Formation in the line of section. Channel deposits are largely composed of lithic arenite sandstones with calcite cement; intra- and extrabasinal lags are present locally, as described below.

\section{Description}

Chignecto Bay Member channel bodies: Two major channel bodies are present in the lower, redbed-dominated Chignecto Bay Member of the Boss Point Formation (Fig. 7). These bodies occur at 23.6 and $56.0 \mathrm{~m}$ and are 8.9 and $4.6 \mathrm{~m}$ thick, respectively. True width:thickness values could not be calculated for these channel bodies because they are incompletely exposed and the western (seaward) channel margins could not be confidently located on air photos. Channels are bounded by fifth-order surfaces that are flat to concave-up near channel margins.

Channel bodies are composed of fine-grained, reddish sandstone that contrasts with the greyish-yellow color of overlying channel bodies. Despite color differences caused by hematite staining, these bodies are composed of lithic arenite sandstone comparable to that in the overlying multistorey bodies. Major internal erosion surfaces are absent and these single-storey channel bodies are filled with stacked sets of cross-beds and ripple cross-laminae (Fig. 7a). Average paleoflow is to the north and northeast $\left(353^{\circ}\right.$ and $049^{\circ}$, respectively), although measurements from the lower body are variable and derived from ripple cross-laminae. A poorly-preserved invertebrate trace fossil, Diplichnites cuithensis, was present on a bedding plane at $56 \mathrm{~m}$, near the top of the channel body (Fig. 7b).

Ward Point Member channel bodies: Fourteen discrete multistorey bodies are present in the Ward Point Member (Fig. 8). Fuller accounts of the sedimentology of these bodies are provided by Browne and Plint (1994) and Ielpi et al. (2014). Thicknesses range from 4.0 to $126.9 \mathrm{~m}(44 \mathrm{~m}$

Figure 8. (following page) Multistorey channel bodies in the Ward Point Member. (a) $>2$-m-thick set of trough cross-beds at $\sim 769 \mathrm{~m}$. This sandy bedform set records the downstream migration of a train of sandy, sinuous-crested dunes. Geologist is $1.7 \mathrm{~m}$ tall. (b) Cross-bedded conglomerate at $\sim 803 \mathrm{~m}$ composed of limestone clasts, mud chips, siderite nodules, and minor extraformational clasts (hammer head rests on base of bed). Similar conglomeratic lags commonly floor erosional surfaces within channel bodies. (c) Detail of conglomeratic interval at $96.5 \mathrm{~m}$ in the measured section. This lag is largely composed of blocky, laminated carbonate likely derived from the underlying Windsor Group. The arrow points to a large clast with visible bedding. (d) Gastropod (Nova Scotia Museum Number 013GF004.001) tentatively identified as genus Strobeus (P. Wagner, personal communication, 2013). This fossil was found in a carbonate-rich lag at $124 \mathrm{~m}$ and was likely derived from reworked Windsor Group carbonates. (e) Conglomeratic erosion surface at $\sim 313 \mathrm{~m}$ with abundant extraformational clasts. (f) Internal erosion surface at $\sim 205 \mathrm{~m}$ lined with an intraformational conglomerate composed almost entirely of mud-chip rip-up clasts. (g) Mudrocks between channel body sandstones at 919-924 m. (h) Large cordaitalean $\log$ at $822 \mathrm{~m}$. Hammer is $32 \mathrm{~cm}$ long, compass is $22 \mathrm{~cm}$ long, and geologists are $\sim 1.7 \mathrm{~m}$ tall. 

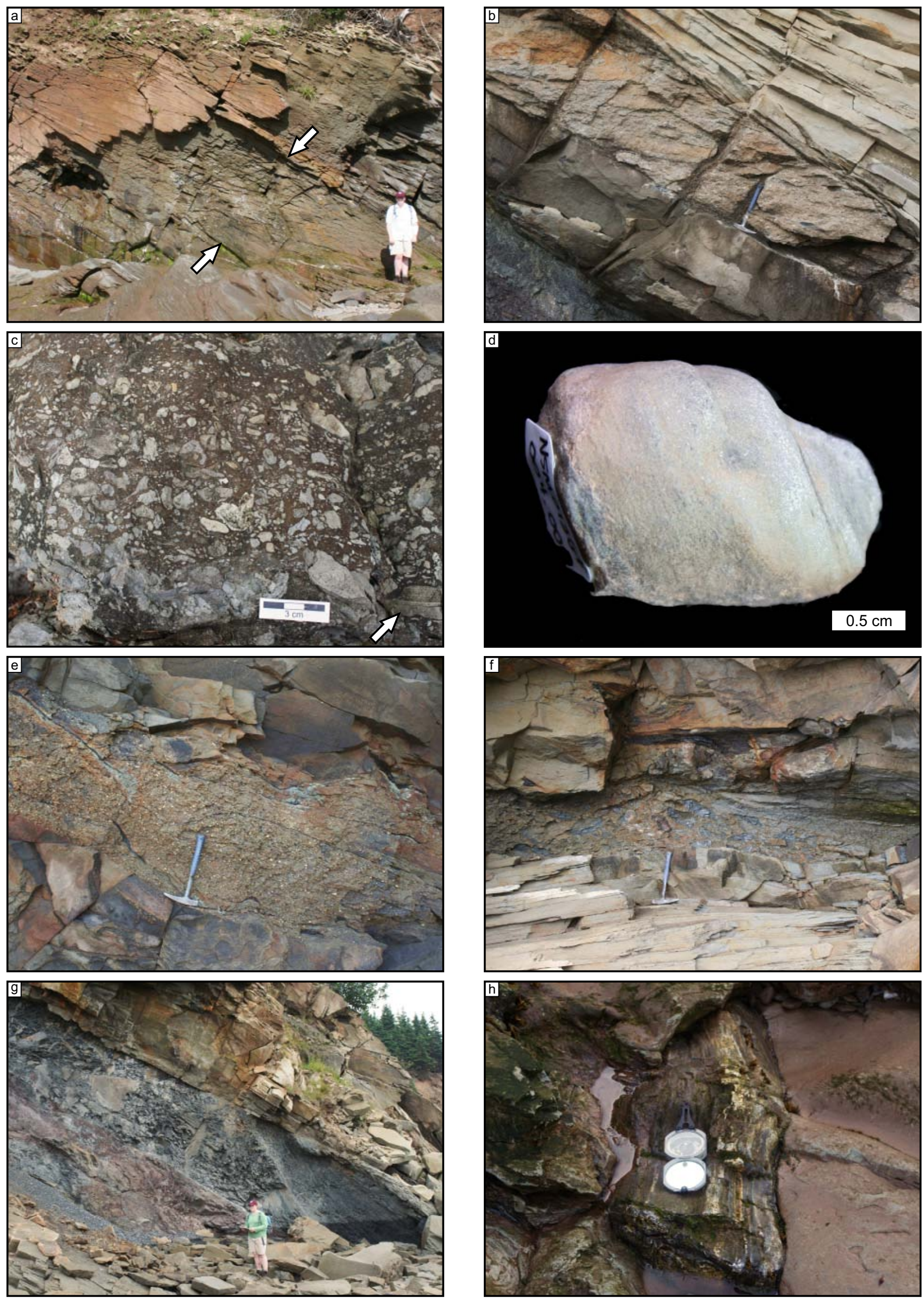
average), with the maximum values near the middle of this interval. Multistorey channel bodies are bounded by sixthor seventh-order bounding surfaces that locally fill valleys with up to $35 \mathrm{~m}$ of erosional relief (Plint and Browne 1994). The basal surfaces can be correlated regionally (Plint and Browne 1994) and these composite channel bodies have minimum W:T values in excess of 300 (Ielpi et al. 2014). Internally, these channel bodies have a complex architecture consisting of cross-cutting fifth- and sixth-order erosion surfaces developed at the base of individual channel elements. Individual storeys range from 2 to $10 \mathrm{~m}$ thick (5.5 $\mathrm{m}$ average). Where fully preserved, individual channel elements range from 1 to $6 \mathrm{~m}$ thick ( $3.5 \mathrm{~m}$ average), 5 to $90 \mathrm{~m}$ wide ( $25 \mathrm{~m}$ avg.), and have average $\mathrm{W}: \mathrm{T}$ values of 7.8 (Ielpi et al. 2014).

Multistorey channel bodies are largely composed of medium- to coarse-grained sandstone organized into trough cross-beds (Fig. 8a). Climbing-ripple cross-laminae and horizontal laminae are abundant in the upper portion of many channel bodies, with some partially preserved antidune bedforms (Allen et al. 2013). Average paleoflow for these 14 channel bodies is $119^{\circ}$ (ranging from $44^{\circ}$ to $\left.161^{\circ}\right)$. These lithofacies comprise composite sandy bars and bedforms, laminated sand sheets, downstream-accretion and minor lateral-accretion macroforms. Subordinate cross-bedded gravel barforms up to $2.0 \mathrm{~m}$ thick are present locally (Fig. 8b). Allen et al. (2013) noted that upper flow regime sand sheets become increasingly common near the top of the member and display Froude transcritical and supercritical structures. Conglomeratic lags composed of intraformational clasts (mud chips, concentrically laminated caliche nodules, and siderite nodules) with subordinate amounts of extraformational material (fragments of igneous, metamorphic, and sedimentary rock) commonly line erosional surfaces in multistorey channel bodies (Figs. 8c-e). Fragments of blocky, horizontally laminated limestone are relatively common between 91.5 and $310 \mathrm{~m}$ (Fig. 8c); an isolated occurrence is present at $\sim 794 \mathrm{~m}$. The cliff exposure at 919 to $924 \mathrm{~m}$ consists of red and green mudrocks that contain large rotated slump blocks and have been intensely affected by soft-sediment deformation (Fig. $8 \mathrm{~g}$ ); this mudrock unit pinches out in the intertidal zone. An abraded gastropod (tentatively identified as Strobeus by P. Wagner, personal communication, 2013) was recovered from a limestone-rich lag at $\sim 124 \mathrm{~m}$ (Fig. 8d).

Transported plant debris in multistorey channels consists largely of logs derived from cordaitalean gymnosperms (Fig. 8h) with minor contributions from lycopsids (Lepidodendron and Lepidophloios), sphenopsids (Calamites), and possible tree ferns and pteridosperms (Ielpi et al. 2014). Falcon-Lang and Scott (2000) documented the presence of charred coniferopsid wood of Dadoxylon-type and noted that permineralized logs consist of pycnoxylic coniferopsid wood that lacked growth rings. Striking examples of large coalified or permineralized cordaitalean logs, many with intact root masses, are particularly common in channel bodies between 110 and $910 \mathrm{~m}$ in the section. Channel lags, small channel fills, and barforms with abundant cordaitalean logs make up $\sim 18 \%$ of the channel fill in multistorey channel bodies (Ielpi et al. 2014). At a few levels, upright cordaitalean trees with preserved roots are encased in channel deposits.

North Reef Member channel bodies: The North Reef (1051.8 $\mathrm{m})$ and South Reef $(1125 \mathrm{~m})$ channel bodies are the only major fluvial sandstones in the North Reef Member. They extend the entire width of the outcrop belt and lack exposed channel margins. The North Reef channel body is $10.5 \mathrm{~m}$ thick and has a minimum W:T value of 12; the South Reef body is $25.0 \mathrm{~m}$ thick and has a minimum $\mathrm{W}: \mathrm{T}$ value of 9.5 . The basal fifth-order erosion surfaces are subhorizontal and have $<3 \mathrm{~m}$ of erosional relief. The North Reef channel body has two intraformational conglomerate-lined erosional surfaces (fifth-order) that split it into three 5-m-thick storeys. Although the South Reef channel body lacks obvious intraformational lags and is less well exposed, it does appear to have laterally extensive erosional surfaces that split it into at least three storeys (Fielding et al. 2011). The South Reef channel body appears to have east-dipping inclined beds that are cut by reactivation surfaces that extend for tens of metres laterally (Fielding et al. 2011).

These channel bodies are largely filled with stacked cosets of trough cross-beds that are bounded by third- and fourth-order surfaces (Fig. 9). Average paleoflow is to the east $\left(84^{\circ}\right.$ and $118^{\circ}$, respectively). Low-angle, convex-upward upper flow regime structures are present at multiple levels in both bodies (Fielding et al. 2011; Allen et al. 2013). Individual sets are up to $2 \mathrm{~m}$ thick near the base of the bodies and thin to $0.5 \mathrm{~m}$ thick near the top. The upper 1-3 $\mathrm{m}$ of the channel fill is composed of ripple cross-laminated, horizontally laminated, and/or low-angle cross-laminated sandstone. Additional details of internal architecture are limited because both bodies were extensively quarried in the 1700s and 1800s (Boon and Calder 2007; Falcon-Lang 2009) and crop out only as low-relief, mud-covered mounds in the intertidal zone. Falcon-Lang and Scott (2000) and FalconLang (2000) reported charred coniferopsid wood fragments of Dadoxylon-type from channel bodies from this interval.

\section{Interpretation}

Chignecto Bay Member channel bodies: The two channel bodies in the Chignecto Bay Member are single-storey deposits whose thickness $(6.8 \mathrm{~m}$ average) roughly approximates the depth of the active channel. The northerly paleoflow recorded by these two bodies is similar to that of the uppermost Claremont Formation (Hamblin 2001) and, more broadly, the Mabou Group (McLeod 2010; Allen et al. 


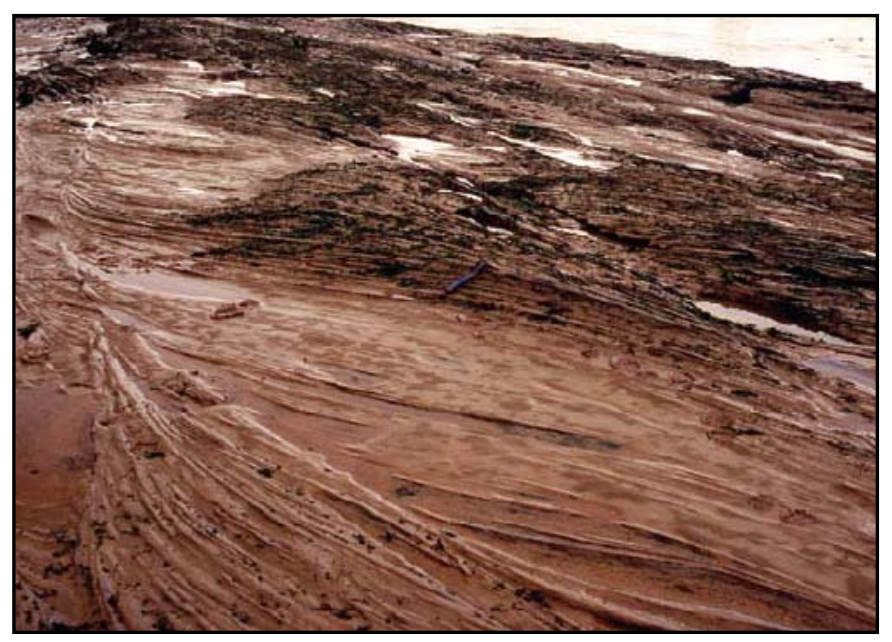

Figure 9. Oblique view of large cross-beds in the South Reef channel body at $\sim 1112 \mathrm{~m}$ in the North Reef Member. Hammer (near centre of photo) is $32 \mathrm{~cm}$ long.

2013), but nearly perpendicular to the southeasterly trend recorded by the overlying multistorey channel bodies of the Ward Point Member. The northerly trend suggests a source area in the Cobequid Highlands (Ryan and Boehner 1994), short-lived tectonic tilting of the basin floor (Plint and Browne 1994), an origin as tributary systems south of the trunk drainage (Gibling et al. 1992), or some combination of these factors.

The sandstone fill is organized into cross-beds and ripple cross-laminae that formed part of downstream accretionary or sandy barforms. Although limited exposure makes more detailed interpretation of fluvial architecture and form difficult, they could represent anastomosed or ephemeral sand-bed rivers (Miall 1996). In terms of style, these deposits likely represent a transition from the arid, strongly seasonal fluvial deposits of the Mabou Group to the perennial braided fluvial deposits of the lower Boss Point Formation (Allen et al. 2013). The presence of Diplichnites (inferred to be the trackway of the large millipede Arthropleura; Briggs et al. 1984) near the top of the channel body at $56 \mathrm{~m}$ suggests that the low-lying abandoned channel may have served as a waterhole in an otherwise moisture-stressed environment (sensu Falcon-Lang et al. 2004).

Ward Point Member channel bodies: Channel bodies in the Ward Point Member are broad sheets with an erosiondominated multistorey architecture; individual storeys and abandoned channel fills are rarely preserved. They can be correlated regionally and mark phases of widespread fluvial deposition in the Cumberland Basin (Plint and Browne 1994; Ielpi et al. 2014). Active channels within the system averaged $5.5 \mathrm{~m}$ deep and $25 \mathrm{~m}$ wide (Ielpi et al. 2014). Although the southeasterly paleoflow recorded by these bodies is comparable to many of the overlying units and consistent with a source in the Caledonia Highlands of New Brunswick or in the Appalachians (Gibling et al. 1992), it is also broadly parallel to the trend of the salt-cored Minudie Anticline and may record paleoflow deflection by the diapir.

Browne and Plint (1994) interpreted these channel bodies as the deposits of braided rivers that were filled with sinuous-crested dunes and confined by stable, vegetated banks. This interpretation was confirmed for the lower part of the member by Allen et al. (2013), who interpreted the lack of upper flow regime structures as a hallmark of perennial channels in a relatively humid climate. Overall, the type of deep, perennial braided river (Miall 2006) envisioned by Allen et al. is comparable to the modern South Saskatchewan River (Cant and Walker 1978) and the Brahmaputra River (Bristow 1993). Comparable ancient deposits include the Kayenta Formation (Miall 1988) and the Westwater Canyon Member of the Morrison Formation (Godin 1991). Allen et al. (2013) noted that upper flow regime structures become increasingly more prominent in channel bodies at higher levels in the member, in accord with an increased degree of seasonality.

The interpretation of multistorey channel bodies in this part of the Boss Point Formation was further refined by Ielpi et al. (2014), who documented floodplains forested by mature cordaitaleans, vegetated islands within the fluvial system as indicated by the presence of rooted channel deposits with upright trees, and numerous accumulations of woody debris at the base of channel storeys or coring large barforms. Given the profound influence of woody plant debris, Ielpi et al. interpreted the multistorey channel bodies as the deposits of anabranching, island-braided sandbed rivers, with morphodynamics similar to those described for the modern Platte River (Horn et al. 2012), the Tagliamento River and other island-braided, wandering, or sandy anabranching systems (Gurnell et al. 2001, Tockner et al. 2003).

Carbonate is present in lags as rounded, concentricallylaminated caliche nodules and as fragments of blocky, laminated limestone. Although the limestone fragments could be intraformational material derived from thin limestones similar to those in the Chignecto Bay Member (see below), a Windsor Group provenance is more likely given the large amount of material, the presence of a large, reworked marine(?) gastropod in a carbonate-rich lag at $\sim 124 \mathrm{~m}$, proximity to the Windsor-cored Minudie Anticline, and the similarity of the Boss Point fragments to Windsor clasts described from the underlying Mabou Group (Hamblin 2001).

North Reef Member channel bodies: The uppermost major channel bodies in the North Reef Member are successiondominated multistorey bodies. These channel bodies were not included in the regional study of Plint and Browne (1994) 
and their lateral extent is unclear. They may have had an original width of at least a few kilometres and were probably narrow to broad sheets with a distribution comparable to multistorey bodies in the underlying members. Individual storeys are 5-8 $\mathrm{m}$ thick and provide a rough approximation of channel depth, an interpretation supported by Fielding et al.'s (2011) hydrodynamic calculations, which suggested bedforms developed in water depths of $4 \mathrm{~m}$. Fielding et al. (2011) and Allen et al. (2013) interpreted the abundance of upper flow regime structures in these bodies as recording a transition from a (sub-)humid to a semi-arid climate with more pronounced seasonality and variability in discharge.

\section{Open water facies association $(\mathrm{OW})$}

\section{Description}

Five occurrences of the open water facies association are present in the Ward Point Member (Fig. 10). Open water intervals range from 1.5 to $9.1 \mathrm{~m}$ thick (average 4.7 $\mathrm{m}$ ) with a cumulative thickness of $23.4 \mathrm{~m}$ ( $2 \%$ of formation thickness; $\sim 8 \%$ of the exposed, non-channelized facies). The open water facies association occurs atop multistorey channel bodies at $101.7 \mathrm{~m}$ (Fig. 10a) and $257.8 \mathrm{~m}$ and atop the poorly drained facies association at $609.1 \mathrm{~m}, 788.1 \mathrm{~m}$, and $950.2 \mathrm{~m}$. It is overlain by multistorey channel bodies at $266.9 \mathrm{~m}$ and $610.6 \mathrm{~m}$, the poorly drained facies association at $783 \mathrm{~m}$, and the well-drained facies association at $109.8 \mathrm{~m}$ and $951.7 \mathrm{~m}$. A sixth occurrence of open water facies occurs interbedded with poorly drained deposits is present between $853.9-875.6 \mathrm{~m}$. Contacts with over- and underlying facies associations range from sharp (generally in association with channel bodies) to gradational over a few tens of centimetres to a few metres.

Greyish-black to grey mudrock devoid of carbonate is the most abundant lithofacies in the open water facies association (Figs. 10b-c). Most intervals are laminated and weather to platy fragments. Flattened siderite nodules concentrated along bedding planes are common. The interval between 854 and $875.5 \mathrm{~m}$ is composed of interbedded, laminated grey mudrocks and blocky greenish-grey mudrocks, both of which appear to have been overprinted by pedogenic processes. Fossils are relatively rare within mudrocks, although unidentifiable plant fragments $(104.5 \mathrm{~m}, 861 \mathrm{~m})$ and ostracods (104.5) are present locally. Mudrocks may become blockier and contain carbonized roots within a few tens of centimetres of contacts with over- and underlying facies associations $(109.5 \mathrm{~m}, 257.8 \mathrm{~m}, 266.9 \mathrm{~m}, 609.1 \mathrm{~m})$. A Stigmaria (lycopsid rhizomorph) with a pyritized rind, which has a $\delta^{34} S$ value of $31 \%$, was recovered from poorly exposed mudrocks in the intertidal zone at $\sim 949 \mathrm{~m}$ (Wagner et al. 2013).

In addition to laminated mudrocks, the two uppermost open water occurrences (788.2-791.9 $\mathrm{m}$ and $950.2-951.7 \mathrm{~m}$ ) have discrete $\sim 1$-m-thick intervals composed of subequal interbeds of limestone and dark-grey shale; individual interbeds range from $0.05-0.27 \mathrm{~m}$ thick (Fig. 10b). Mudrocks within these interbedded packages are similar to those described above. Limestones range from light-grey, well-cemented wackestones that stand in prominent relief to greyish-black, organic-rich packstones with a more fissile and papery weathering pattern. Ostracods are present in both types of limestone; the organic-rich packstones have abundant bivalves that partially define bedding planes. Vasey (1984) assigned bivalves of the Boss Point Formation to the genera Carbonicola and Curvirimula. Grey et al. (2012) reported the ostracod Velatomorpha altilis from open water deposits near the top of the Boss Point Formation.

A fissile calcareous black shale with abundant bivalves and ostracods is present at $106.9 \mathrm{~m}$. A single, $<0.01$-m-thick discontinuous coal is present within greyish mudrocks at $610.2 \mathrm{~m}$. The coal sits atop $0.25 \mathrm{~m}$ of blocky dark-grey mudrock; no roots were observed.

\section{Interpretation}

The open water facies association was deposited in calm bodies of water that ranged from fresh to brackish and was generally of sufficient depth to limit plant growth. We consider only intervals with direct evidence of deposition in a relatively long-lived standing body of water to be part of this facies association. This approach contrasts with that of Plint and Browne (1994) and Browne and Plint (1994) who included all relatively fine-grained, non-channelized deposits in their lacustrine facies.

We agree with Plint and Browne's (1994) interpretation that dark-colored laminated mudrocks were deposited in a reducing, organic-rich environment where mud accumulated by suspension deposition. Browne and Kingston (1993) analyzed sphaerosiderite from mudrocks at $\sim 609 \mathrm{~m}$ in our section and determined that the body of water must have experienced reducing, stagnant conditions and contained a sufficiently low amount of dissolved sulfate to be considered of freshwater origin.

The significance of a thin coal within the open water facies association depends on its origin: given its discontinuous nature and lack of underlying roots, it likely represents organic material (vitrain) resulting from coalification of a transported lycopsid log rather than an in-situ histosol (peat). Plint and Browne (1994) described upright lycopsids entombed in grey platy "lacustrine" mudstones. Unlike mires which have a peat substrate, these clastic swamps developed atop a mineral soil (Gastaldo 1987; Demko and Gastaldo 1992).

The ostracod- and bivalve-bearing limestones, part of Plint and Browne's (1994) abandonment facies, record deposition of carbonate in an environment with very little 

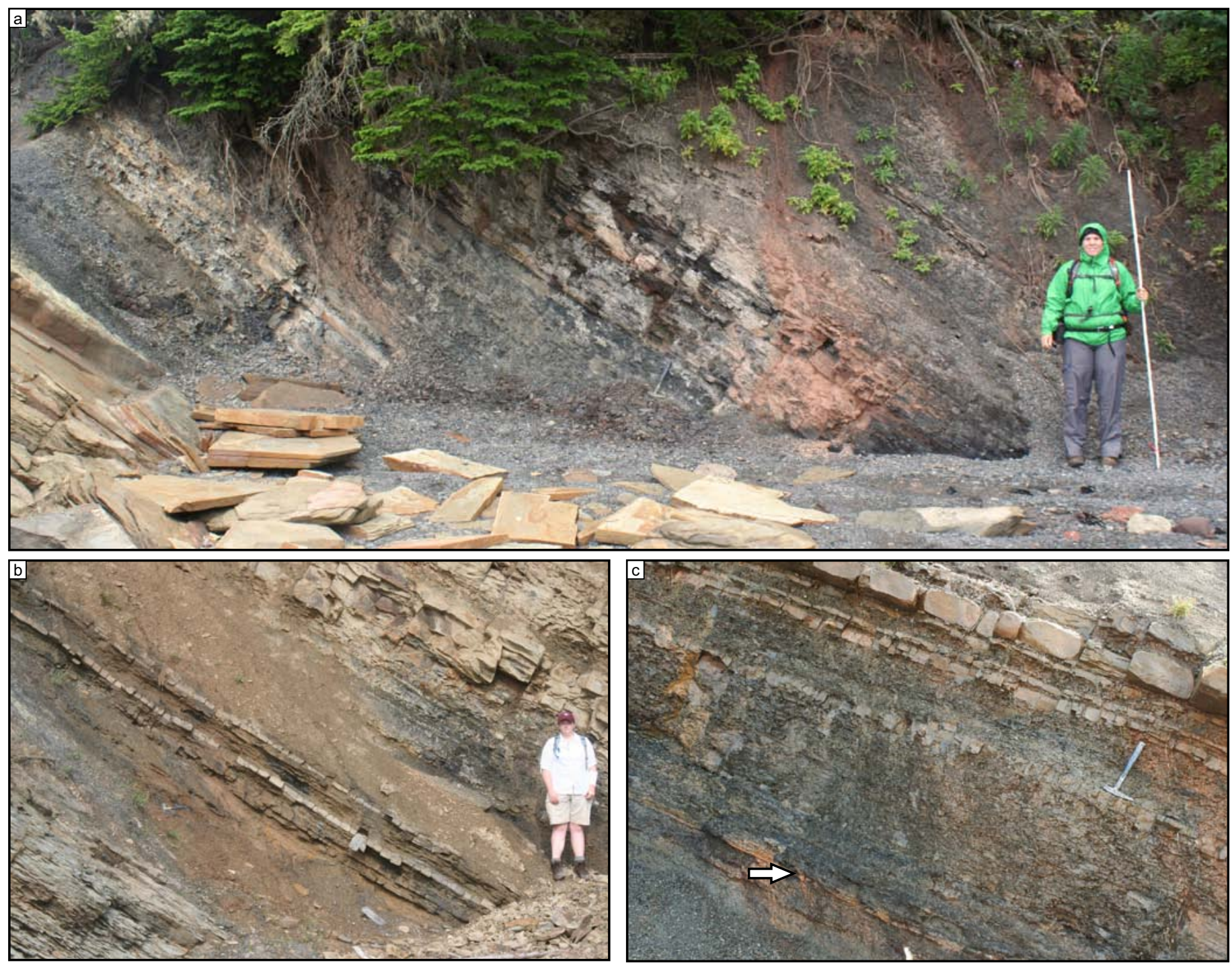

Figure 10. Open water facies association (OW). (a) View of deposits between 101.7-109.8 $\mathrm{m}$ in the measured section. This interval is composed of laminated dark-grey and black shales with scattered bivalves, ostracods, plant fragments, and siderite nodules. It is separated from the underlying channel sandstone by a sharp basal contact. (b) Detail of open water facies between 788.2-791.9 m showing dark, laminated mudrocks and tabular limestones (two pale beds at centre). (c) Interbedded open water and poorly drained deposits at $869-874 \mathrm{~m}$ in the measured section. The arrow points to the 0.06-m-thick coal at $870.4 \mathrm{~m}$. It is overlain by platy grey shales deposited from suspension in a standing body of water; the shales are in turn overlain by thin sheet sandstones and green mudrocks deposited on a poorly-drained floodplain. Hammer is $32 \mathrm{~cm}$ long and geologists are $\sim 1.7 \mathrm{~m}$ tall.

clastic input. These limestones have striking lithologic and faunal similarities to the "bituminous limestones" of the Joggins Formation (Davies and Gibling 2003; Davies et al. 2005). The low diversity and high abundance of ostracod and bivalve fossils suggests oligotrophic conditions determined by oxygen levels, salinity, or other types of environmental stress (sensu Ielpi 2013). Sulfur isotope values suggest that the pyritized Stigmaria just below the ostracod-bearing open water interval at $950 \mathrm{~m}$ most likely formed in a closed system that had considerable amounts of dissolved sulfate - conditions suggestive of brackish water (Wagner et al. 2013). Although a growing body of evidence suggests a marginal marine setting for these deposits (Skilliter 2001; Falcon-Lang 2005; Tibert and Dewey 2006; Grey et al. 2011; Bashforth et al. 2014), much uncertainty exists and further work is needed to fully understand their paleoenvironmental significance (Calder 1998; Falcon-Lang et al. 2006).

The terms "lake", "bay", or "lagoon" may be applicable 
to these standing bodies of water depending on the water chemistry at the time of deposition. Regardless of the exact terminology used, they clearly suggest low-energy bodies of water where suspension deposition of mud and/ or precipitation of carbonate were the dominant processes. Unlike open-water intervals in the overlying Joggins Formation, the transition to floodplain facies is not marked by a wave- or fluvial-dominated package of sharp-based sandstones (Davies and Gibling 2003). Rather, the bodies of water in the Ward Point Member appear to record a gradual shallowing and a transition to muddy floodplains marked by an increase in blockiness and abundance of carbonized roots. Overall, these bodies of water may have had some sedimentological and ecological similarities to Lake Pontchartrain (Manheim and Hayes 2002). In terms of ancient analogs, these deposits may represent a more humid climate version of the Oligocene deposits of the Calaf Basin (Cabrera and Saez 1987).

\section{Poorly drained facies association (PD)}

\section{Description}

Seven occurrences of the poorly drained facies association are present in the Ward Point Member between 168 and $950 \mathrm{~m}$ in the measured section (Fig. 11). Individual intervals range from 2.0 to $15 \mathrm{~m}$ thick (average $7.7 \mathrm{~m}$ ) with a cumulative thickness of $53.8 \mathrm{~m}$ (5\% of formation thickness; $\sim 18 \%$ of the exposed non-channel facies). Occurrences of poorly drained strata are present atop multistorey channel bodies (168.3 m, $415.8 \mathrm{~m}, 607.1 \mathrm{~m}, 780.8 \mathrm{~m}$, and $935.1 \mathrm{~m}$ ), the open water facies association (791.9), and a covered interval $(749.2 \mathrm{~m})$. Contacts with over- and underlying facies associations range from sharp to gradational over a few tens of centimetres (Fig. 11a). A complexly interbedded package of open water and poorly drained deposits is present at $854.0-875.5 \mathrm{~m}$; contacts between constituent facies were overprinted by pedogenic processes and this interval could not be confidently subdivided.

Green and grey mudrocks are the most common lithology in the poorly drained facies association (Fig. 11b). Beds are up to $2 \mathrm{~m}$ thick and have sharp to gradational contacts with other lithologies. Internally, mudrocks range from platy to blocky with little or no obvious internal stratification. Many contain scattered siderite nodules and vertically oriented carbonized roots. Stigmaria occur in association with mineral paleosols and beneath organic-rich horizons. Plint and Browne (1994) documented Stigmaria at positions equivalent to $\sim 169 \mathrm{~m}, 754 \mathrm{~m}$, and $854-874 \mathrm{~m}$ and in-situ lycopsid trunks at $\sim 869 \mathrm{~m}$ and $\sim 872 \mathrm{~m}$.

Dark-grey to greyish-black organic-rich horizons up to $0.02 \mathrm{~m}$ thick are common within mudrocks of the poorly drained facies association. They commonly overlie intervals with a blocky fabric, abundant carbonized roots, and limonite staining.

Rare $<2$-m-thick zones of reddish brown mudrock are present locally $(171.5 \mathrm{~m}, 752.5 \mathrm{~m}, 801.5 \mathrm{~m}, 948.5 \mathrm{~m}$, and several horizons between 851 and $875 \mathrm{~m}$ ). Reddened intervals typically have gradational contacts with overand underlying greenish-grey mudrocks and may contain siderite nodules, carbonized roots, and diffuse organicrich horizons. A $\sim 1$-m-thick blocky red mudrock at 171.5 $\mathrm{m}$ contains calcareous nodules. This unit has a gradational contact with underlying greenish-grey mudrocks and a sharp contact with overlying greenish-grey mudrocks with carbonized roots.

Two $0.06-\mathrm{m}$-thick coals are present within poorly drained strata at $174.5 \mathrm{~m}$ and the interbedded open water/ poorly drained interval at $870.4 \mathrm{~m}$. The lower coal has several thin shale partings and sits atop a blocky greengrey mudrock with carbonized roots and limonite staining. The upper coal occurs above a blocky greenish-grey shale with siderite rhizoconcretions and below a laminated grey shale. The upper surface of the coal has numerous flattened, coalified lycopsid logs.

Sheet sandstones become particularly abundant above $609 \mathrm{~m}$. Together with minor channel bodies, they make up $<10 \%$ of the thickness of poorly drained occurrences below $780.8 \mathrm{~m}$ and up to $60 \%$ of their thickness above this level. Individual beds are generally $<1 \mathrm{~m}$ thick and have sharp contacts with over- and underlying mudrocks. Most sandstones contain ripple cross-laminae (in places climbing ripples) and flattened siderite nodules; horizontal lamination and cross-bedding are present locally. Minor channel sandstones occur locally in association with sandstone-rich intervals. Many sandstones are internally massive; vertical carbonized roots and plant fragments are common. Radiating carbonized roots associated with Stigmaria are present at $608.9 \mathrm{~m}, 856.3 \mathrm{~m}, 861.6 \mathrm{~m}$, and $873.9 \mathrm{~m}$. Although lycopsid trunks were not observed during this study, in-situ examples were reported from this section by Plint and Browne (1994) and rare, transported Lepidodendron and Lepidophloios were noted in the channel sandstones described above (Ielpi et al. 2014). Entombed Calamites are common within sandstones above $609 \mathrm{~m}$ (Fig. 11c).

\section{Interpretation}

The poorly drained facies association was deposited in low-lying swampy areas saturated with oxygen-depleted water. Mudrocks record suspension deposition on the floodplain; blocky textures and roots within these beds record the development of immature hydromorphic paleosols and colonization by vegetation. Localized reddish brown mudrocks within poorly drained deposits record relatively modest exposure and drainage, likely due to seasonal lowering of the water table that allowed for oxidation of the 

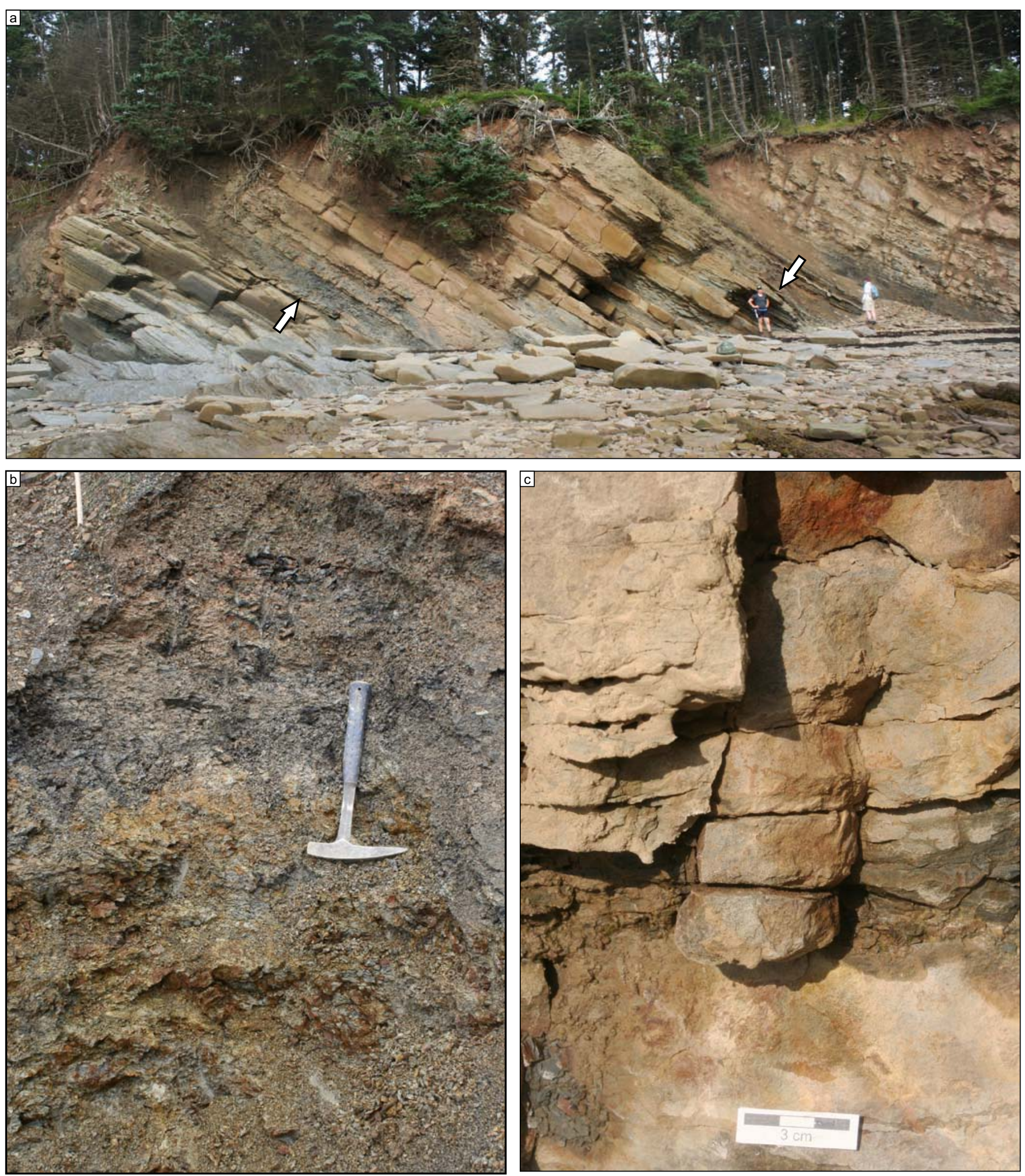

Figure 11. Poorly drained facies association (PD). (a) Strata deposited atop a major channel body (left arrow points to top of channel deposits at $780.8 \mathrm{~m}$ ) and beneath open-water deposits (right arrow shows their base at $788.2 \mathrm{~m}$ ). In addition to the blocky grey mudrocks characteristic of the facies association, sheet sandstones (to left of figures) become increasingly abundant near the top of the formation. (b) Detail of grey blocky mudrocks at $174 \mathrm{~m}$. (c) In-situ Calamites entombed in sheet sandstone at $792.5 \mathrm{~m}$. Hammer is $32 \mathrm{~cm}$ long and geologists are $\sim 1.7 \mathrm{~m}$ tall. 
substrate. Organic-rich horizons and thin coals represent histic epipedons and short-lived histosols developed in localized, incipient peat-forming or clastic wetlands (Retallack 2008). Although Plint and Browne (1994) did not observe coals in the type section, they documented examples up to $0.7 \mathrm{~m}$ thick in other exposures, indicating that longer-lived mires may have existed elsewhere on the Boss Point floodplain.

Sheet sandstones represent crevasse-splay deposits formed when floodplain channels overtopped their banks and deposited a veneer of sand across the floodplain. Minor channel bodies within sheet sandstones represent either crevasse-splay feeder channels formed as the main channel was breached, or distributary channels formed where fluvial systems debouched into wetlands. Sandstone-rich intervals with numerous closely spaced interbeds of mudrock may represent avulsion deposits formed in close proximity to the major channels (Kraus and Wells 1999).

Additional information about the poorly drained facies association was provided by Ielpi et al. (2014), who documented the general composition of plant material, described several occurrences of in-situ vegetation, and placed this paleobotanical information into an environmental context. Sandstone-rich crevasse-splay deposits were occupied by Calamites, a horsetail-like plant that was well adapted to the colonization of disturbanceprone environments (Gastaldo 1992; Pfefferkorn et al. 2001; Calder et al. 2006). Stigmarian rhizomorphs within clastic paleosols and beneath organic-rich horizons record the former presence of lycopsids in wetland environments, both in clastic swamps and incipient peat-forming mires on the floodplain. The two fossil genera of lycopsids (Lepidodendron and Lepidophloios) had an ecological preference for the most waterlogged and stable (i.e., undisturbed) parts of peatforming mires or clastic swamps (Phillips and DiMichele 1992; DiMichele and Phillips 1994). Likewise, the wetlands that supported these spore-bearing lycopsids must have been sufficiently persistent for germination and growth of these trees (DiMichele and Phillips 1994).

\section{Well drained facies association (WD)}

\section{Description}

Eight occurrences of the redbed-dominated well drained facies association are present (Fig. 12). Welldrained deposits are the only non-channelized deposits in the Chignecto Bay and North Reef members. Individual occurrences range from 6.2 to $89.5 \mathrm{~m}$ thick and the cumulative thickness is $193 \mathrm{~m}$ (17\% of formation thickness; $66 \%$ of exposed, non-channelized facies). Although thick covered intervals are present near the base and top of the section, shifting exposures of mudrock in the intertidal zone appear to be composed almost entirely of redbeds.
It is probable that much of the $\sim 160 \mathrm{~m}$ of covered section consists of well-drained deposits. In the Ward Point Member, strata of the well drained facies association occur atop the open water facies association $(109.8 \mathrm{~m}$ and 951.7 $\mathrm{m})$, the poorly drained facies association $(176.3 \mathrm{~m}, 875.5$ $\mathrm{m}$ ), and multistorey channel bodies (393.8 $\mathrm{m}$ and $473.8 \mathrm{~m}$ ). Contacts with other facies associations are generally sharp, although they may be interbedded or gradational over a few tens of centimetres.

Reddish brown mudrocks (Munsell rock colors 10R $3 / 4$ to $10 \mathrm{R} 4 / 6$ ) are the most abundant lithology in the well drained facies association (Fig. 12d). They comprise $>80 \%$ of the thickness of well-drained deposits below $875.5 \mathrm{~m}$ and $50-60 \%$ of its thickness above this level. Grain size ranges from silty claystone to siltstone. Internal fabrics range from platy to blocky and many become progressively blockier upward. A few siltstones contain ripple cross-laminae. Polished pedogenic slickensides were observed in mudrocks at several levels ( $178.6 \mathrm{~m}, 189.7 \mathrm{~m}$, and $1027.3 \mathrm{~m}$ ) and curved vertic structures with up to $0.5 \mathrm{~m}$ of vertical extent are present in blocky red mudrocks at $39.5 \mathrm{~m}$. Polygonal desiccation cracks are present locally; those at $1028.8 \mathrm{~m}$ are filled with organic-rich material from overlying beds. Redbeds with calcareous nodules are present throughout the formation; nodules are generally scattered (Machette's 1985 Stage I or II), although a dense, partially coalesced horizon (Machette's 1985 Stage III) is developed atop a sandstone at $1026.3 \mathrm{~m}$ (Fig. 12e). Gardiner (2005) documented the presence of pedogenic mud aggregates in laminated siltstones, mudchip rip-up clasts, and carbonate rhizoconcretions in an interval that corresponds to the 952-1041 m interval in our measured section. Pedogenic mud aggregates may also be present within a mudrock-filled scour at $184 \mathrm{~m}$ (Fig. 12c); this interval contained a calcite-cemented intraformational conglomerate composed of caliche nodules, rip-up clasts, and sand-sized mudrock aggregates. A variety of mudaggregate morphologies, including dark hematite-stained claystone and silty mudstone, are present in this lag and many have indented contacts.

Scattered green horizons $(<0.5 \mathrm{~m}$ thick) and diffuse, irregular mottles are common within red mudrocks and also occur locally in association with discontinuous organic-rich bands $(<0.01 \mathrm{~m}$ thick) or isolated plant fragments. Vertical carbonized roots are ubiquitous and many are surrounded by reduction haloes. Vertically oriented, unbranched calcareous rhizoconcretions are present in red mudrocks at $179 \mathrm{~m}$. A sandstone cast of Stigmaria was observed in red mudrock just above greenish-grey bands at $996.8 \mathrm{~m}$ (Fig. 12f); Plint and Browne (1994) observed Stigmaria in reddish-grey mudrocks at $\sim 479 \mathrm{~m}$ and in-situ lycopsids at $\sim 881 \mathrm{~m}$.

Sheet sandstones are common in well-drained intervals (Fig. 12a). Below $875.5 \mathrm{~m}$ they are generally $<1$-m-thick, isolated, and comprise less than $20 \%$ of the thickness 

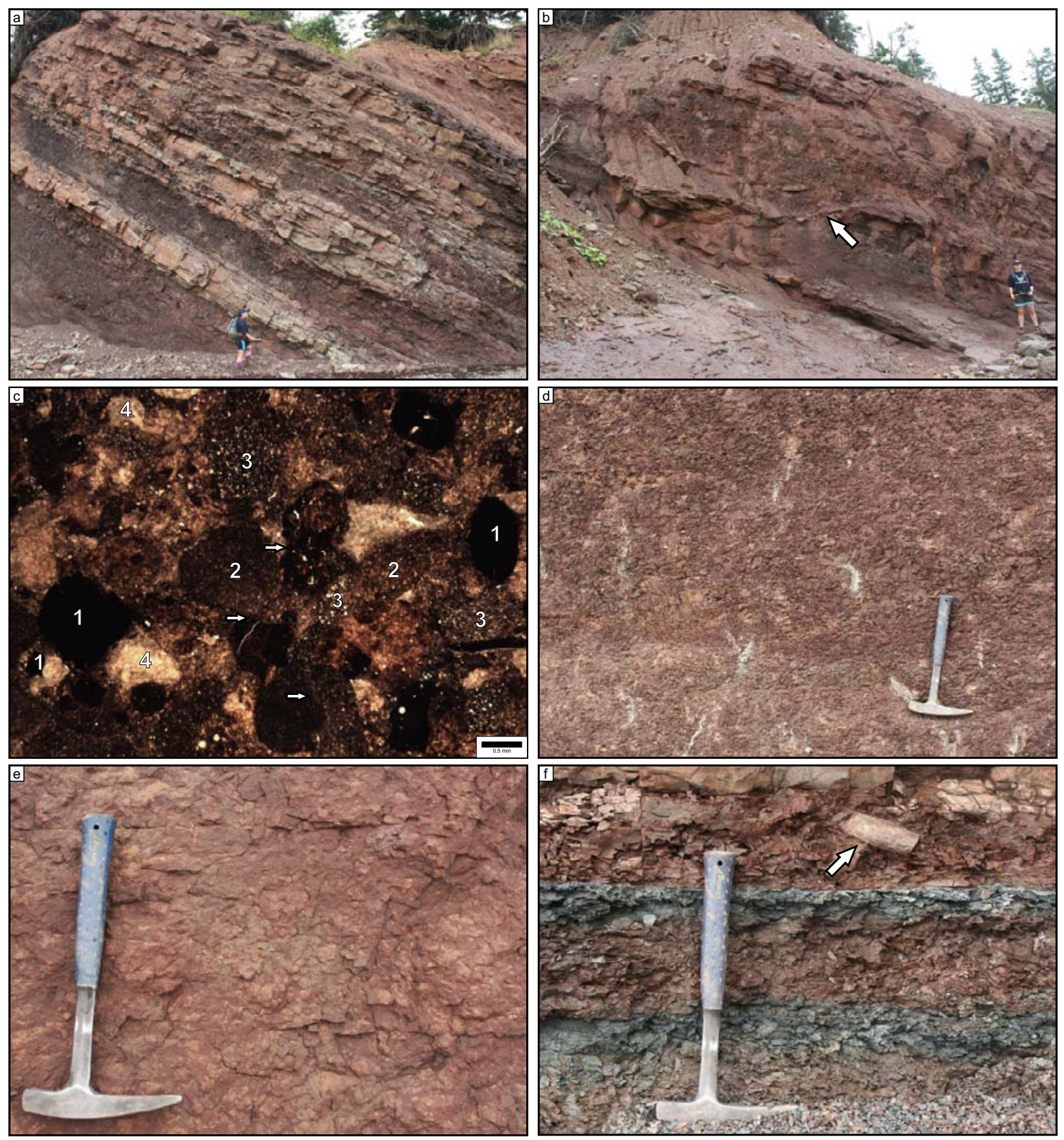

Figure 12. Well drained facies association (WD). (a) View of interbedded sheet sandstones and blocky red mudrocks between $\sim 963$ and $\sim 983 \mathrm{~m}$. Although relatively thin and rare in the bottom half of the formation, sheet sandstones make up well over half of the thickness of facies association occurrences above $\sim 875 \mathrm{~m}$. (b) Mudrock-filled channel body at $\sim 1028$ m. (c) Photomicrograph of pedogenic mud aggregates within a calcite-cemented intraformational conglomerate at $\sim 184$ $\mathrm{m}$. Many aggregates appear to have been deformed by adjacent grains, suggesting that they were semi-consolidated at the time of burial. Numbers indicate lithologies within the sand-sized fraction: (1) dark hematite-stained claystone, (2) silty claystone, (3) silty mudstone, and (4) transported calcareous fragments, likely abraded caliche nodules. (d) Calcareous rhizoconcretions in blocky red mudrock at $179 \mathrm{~m}$. (e) Bedding-plane exposure of caliche nodules developed atop a sheet sandstone at $1028.5 \mathrm{~m}$. (f) Organic-rich bands and sandstone-cast Stigmaria (lycopsid rhizomorph; arrowed) in blocky reddish brown mudrocks at $997 \mathrm{~m}$. The presence of stigmarian rhizomorphs within these redbeds indicates either postdepositional reddening or the presence of clastic swamps that experienced occasional drying despite maintaining sufficient water to allow for lycopsid growth. Hammer is $32 \mathrm{~cm}$ long and geologists are $\sim 1.7 \mathrm{~m}$ tall. 
of this facies association. Above $875.5 \mathrm{~m}$ they become thicker (commonly $>1-\mathrm{m}$-thick), occur in groups to form sandstone-rich intervals within well-drained deposits, and comprise $20-50 \%$ of the facies association thickness. Ripple cross-laminae and horizontal laminae are common; crossbeds $<0.5 \mathrm{~m}$ thick are present locally. Many sheet sandstones have vertical carbonized roots and a blocky fabric caused by the destruction of stratification. Minor sandstone-filled channel bodies $(<4 \mathrm{~m}$ thick) are commonly associated with sandstone-rich intervals in well-drained deposits. A partially mudrock-filled channel body is contained within a sandstone-rich package at $\sim 1027 \mathrm{~m}$ (Fig. 12b). Tetrapod trackways are present in thinly bedded siltstone and sandstone beds within the North Reef Member (Brian L. Hebert, personal communication, 2013).

Four grey limestones ranging in thickness from 0.06 to $0.15 \mathrm{~m}$ are present within reddish-brown mudrocks in the Chignecto Bay Member between 0 and $50 \mathrm{~m}$ (Fig. 13). These lime mudstones are separated from the over- and underlying redbeds by sharp contacts. The limestone at $41 \mathrm{~m}$ sits atop a $<2 \mathrm{~cm}$ grey gleyed horizon developed atop a blocky mudrock with well-developed vertic structures. Bedding-plane exposures of this limestone have desiccation cracks that penetrate 1-2 cm down from the top of the bed (Fig. 13a). The limestone is overlain by platy to blocky red mudrocks that are similar to those that encase the overlying limestones. Although body fossils were not observed macroscopically, petrographic analysis of the limestone at $41 \mathrm{~m}$ revealed a gastropod fragment, and possible ostracods and sinuous algal or cyanobacterial filaments (Fig. 12c). The overall lack of fossils, light-grey color, and sedimentological context of limestones within the well drained facies association makes them easy to distinguish from the dark-grey, organic-rich limestones of the open water facies association.

\section{Interpretation}

The well drained facies association was deposited in a floodplain environment where subaerial exposure and drainage conditions caused oxidation of iron and

Figure 13. Details of the limestone at $41 \mathrm{~m}$, one of four nearly identical thin limestones developed in redbeds of the Chignecto Bay Member. (a) Outcrop photograph showing blocky structure and curved vertic structures (arrowed) in redbeds beneath limestone (with hammer on top) and more platy redbeds above. Hammer is 32 cm long. (b) Bedding plane view of talus blocks showing desiccation cracks developed in the top of the limestone. (c) Photomicrograph (plane-polarized light) showing possible algal filaments in fine-grained, micritic zone within the limestone (to the right of arrows). Adjacent areas appear to be partially recrystallized pelmicrite.
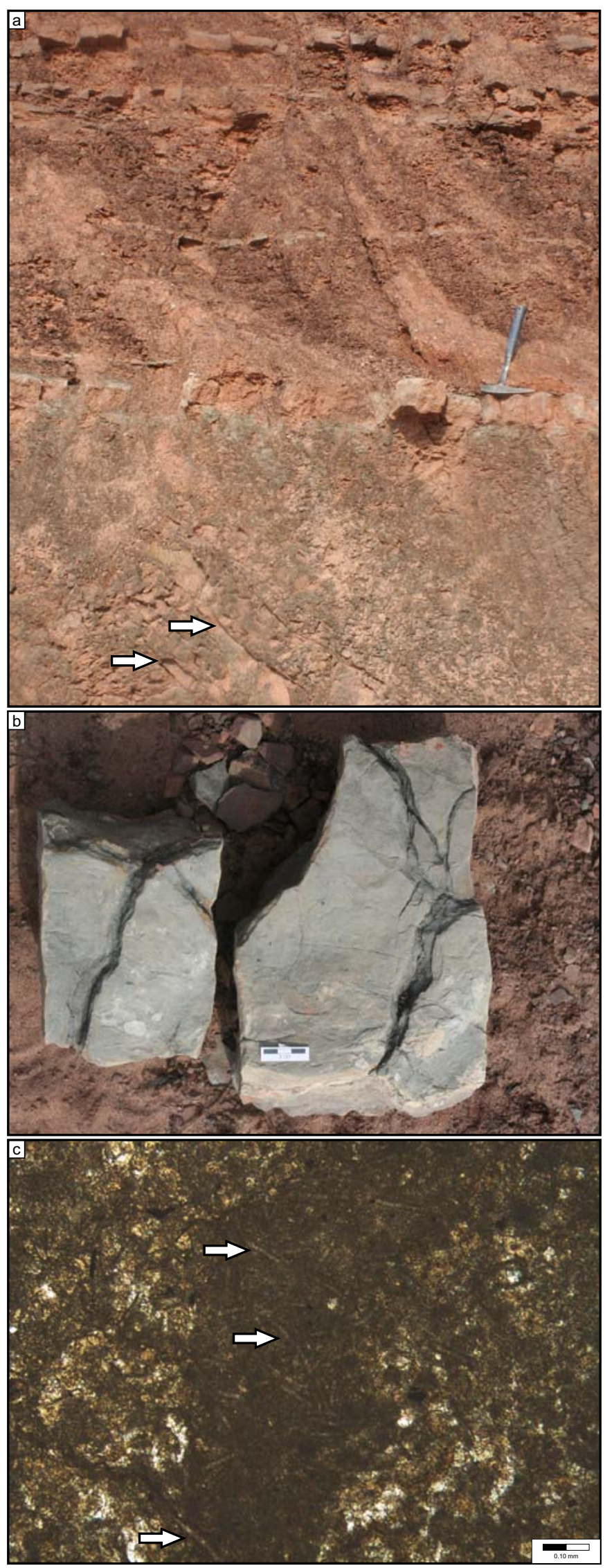
decomposition of organic material. Mudrocks were deposited through suspension deposition and later transformed into paleosols that record a variety of types, maturities, and processes.

Platy to blocky redbeds with scattered roots and poorly developed horizons represent entisols and inceptisols. They were buried before well differentiated horizons could form and appear broadly similar to the immature redbed paleosols described from the Joggins and Springhill Mines formations (Davies et al. 2005; Rygel et al. 2014). Scattered organic-rich horizons, green mottles, and rare Stigmaria within redbeds suggests that some of these mudrocks were clastic wetlands where there was sufficient water to allow partial preservation of organics and growth of lycopsids. These former wetland soils developed their reddish-brown color either in response to seasonal water-table fluctuations that caused shortlived oxidizing events within wetland soils (Roberts et al. 1981) or post-depositional reddening associated with early diagenesis (Walker 1967; Retallack 2001).

Wetland features within the well drained facies association are relatively rare and most paleosols formed under oxidizing conditions developed in response to regional paleoclimate or on localized paleotopographic highs that afforded good drainage (Roberts et al. 1981; Calder et al. 2005). Browne and Plint (1994) and Plint and Browne (1994) report vertisols and aridisols regionally and interpret them as having formed in a semi-arid climate with pronounced rainfall seasonality. These observations are consistent with ours in the type section, where numerous intervals below $479 \mathrm{~m}$ (and at $1026.3 \mathrm{~m}$ ) have vertic structures and subsurface accumulations of pedogenic carbonate. These paleovertisols probably formed in a tropical environment with a sub-humid to semi-arid climate $(180-1520 \mathrm{~mm}$ annual precipitation) and pronounced rainfall seasonality (Caudill et al. 1996; Retallack 2001).

The interpretation of wet-dry seasonality is reinforced by the presence of pedogenic mud aggregates near the top (Gardiner 2005) and bottom of the formation. Pedogenic mud aggregates are sand-sized particles of mud formed in soils with expandable clays developed under a warm climate with wet-dry seasonality (Gierlowski-Kordesch and Gibling 2002). Although it is certainly possible that some of the larger particles represent intraformational ripup clasts, the examples described in this study (Fig. 12c) are best interpreted as transported aggregates because: they lack pronounced internal stratification; have variable composition; occur in beds with sharp contacts with underlying units; coexist with reworked carbonate nodules; and have rounded edges (Müller et al. 2004). Although they may also be present in paleosols, pedogenic mud aggregates are best seen in channel deposits such as the one at $184 \mathrm{~m}$ where they can be protected from compaction by robust framework grains or by early calcite cement (Fig. 11c; Rust and Nanson 1989; Gierlowski-Kordesch and Gibling 2002).
Indented contacts in aggregates suggest that they were semiconsolidated at the time of deposition. Tetrapod trackways provide additional evidence for subaerial exposure and presence of a firm substrate.

As in the poorly drained facies association, sheet sandstones and associated minor channels represent crevasse-splay deposits. These rapidly aggrading, disturbance-prone environments were colonized by dense thickets of Calamites, which could colonize disturbed habitats due to their free-sporing strategy and ability to regenerate after burial (Gastaldo 1992; Calder et al. 2006). Although scattered throughout well-drained intervals in the lower part of the formation, sandstone-rich intervals with abundant closely-spaced sandstone interbeds become particularly abundant above $940 \mathrm{~m}$, a trend that Ielpi et al. (2014) interpreted as representing increased seasonality. The sandstone-rich overbank motif is similar to well-drained deposits in the overlying Joggins and Springhill Mines formations (Davies et al. 2005; Rygel et al. 2014).

The four limestones present in redbeds of the Chignecto Bay Member were deposited in ephemeral floodplain lakes. Unlike limestones in the open water facies association, they are penetrated by desiccation cracks, contain only a few rare macrofossils, and are not associated with any other obviously open-water features (e.g., laminated mudrocks). Broadly similar limestones within redbed-dominated intervals have been described from the Hastings Formation in western Cape Breton (Hamblin 2001) and the Dunkard Group of the Appalachian Basin (Montañez and Cecil 2013).

Interpretation of well-drained floodplains within the Boss Point system was confirmed by Ielpi et al. (2014), who examined transported plant material within multistorey channel bodies. Locally derived cordaitalean gymnosperm material made up the overwhelming majority of the plant fossils. These slow-growing trees, which occupied welldrained riparian areas, floodplains, and basin-margin uplands, preferred the type of stable, seasonally dry conditions recorded by the redbed paleosols described above (Falcon-Lang 2003; Falcon-Lang et al. 2004, 2009; DiMichele et al. 2010; Bashforth et al. 2011, 2014).

\section{DISCUSSION}

\section{Sediment transport}

Channel bodies of the Mabou and Cumberland groups exposed in the Joggins section overwhelmingly record sediment transport to the east and southeast, away from source areas in the Caledonia Highlands and beyond (Gibling et al. 1992; Rygel and Gibling 2006; Allen et al. 2013; Rygel et al. 2014). Noteworthy exceptions include a number of north-flowing channel bodies in the Mabou 
Group (Hamblin 2001; McLeod 2010; Allen et al. 2013), north-flowing channel bodies in the Chignecto Bay Member of the Boss Point Formation, northwest-oriented paleoflow indicators in the upper storey of the South Reef channel body (Fielding et al. 2011; North Reef Member of the Boss Point Formation), and southwest-flowing channel bodies of the Little River Formation (Calder et al. 2005). These rivers eventually joined trunk systems that flowed to the northeast toward the center of the Maritimes Basin and away from the convergence of the bounding highlands (Gibling et al. 1992; Bashforth et al. 2014).

Browne and Plint (1994) documented a range of paleoflow directions for the Boss Point Formation in New Brunswick and Nova Scotia, with a generally northeasterly direction in the eastern Cumberland Basin. They reported an intriguing regional paleoflow anomaly in the western Cumberland Basin. Boss Point outcrops south of the Hastings Fault and Minudie Anticline (including the type section), have a strong southeasterly trend whereas those to the north of the fault and anticline have a strong northerly trend. They attributed this pattern to sinistral rotation along the fault, which juxtaposed the two divergent paleoflow domains. In addition to the northerly paleoflow anomaly in the Boss Point Formation, recent work on over- and underlying units reveals comparable anomalies within the Joggins section (Hamblin 2001; Calder et al. 2006; McLeod 2010; Allen et al. 2013).

An alternate interpretation to strike-slip rotation is that Pennsylvanian rivers in the Cumberland Basin were deflected by salt diapirs (Ryan 1985; Gibling et al. 1992). In a situation very similar to the one described by Browne and Plint (1994), Ryan (1985) documented opposing paleoflow measurements associated with the crest of a salt diapir in the Tatamagouche area.

Given the profound influence and the timing of salt tectonics in the western Cumberland Basin, we favor the salt tectonic explanation for the observed paleoflow anomalies and can reconcile these observations with the halokinetic history provided by Waldron et al. (2013). We postulate that the north-directed paleoflow measurements in the Mabou Group and lower Boss Point Formation record a period of halokinetic quiescence resulting from the deposition of a blanket of sediment of relatively uniform thickness (phases iii and iv of Waldron et al. 2013). The even thickness of the Mabou Group in the western Cumberland Basin suggests that significant halokinesis had not yet begun and that the salt-cored Minudie Anticline had yet to develop. During this phase of deposition, rivers would have flowed out of the basin to the north with little or no deflection.

With the onset of Ward Point-style sedimentation the basin was repeatedly, and perhaps rapidly, blanketed with sheets of braided fluvial sandstone derived from a trunk fluvial system sourced in the Caledonia Highlands and rising Appalachians beyond. Although the earliest history of
Minudie Anticline movement has been removed by erosion of the diapir crest and flank, seismic data suggest that modest salt movement was taking place during deposition of the Boss Point Formation (Waldron et al. 2013). This phase of modest passive diapirism would have been driven by localized differential loading that would have created the diapir and kept its crest at or near the sediment surface, possibly creating a subtle paleotopographic high (Al-Zoubi and ten Brink 2001; Banham and Mountney 2013, 2014). During this intermediate step between phases iv and $\mathrm{v}$ of Waldron et al. (2013), paleotopography was sufficient to deflect paleoflow to the southeast so that it paralleled the crest of the salt wall before eventually turning north. This scenario is consistent with the presence of Windsor Group limestone clasts (see above) and reworked Mississippian spores (Utting et al. 2010) within the Boss Point Formation.

The sudden shift to sand-poor facies of the Little River Formation corresponds with an abrupt shift to southwesterly paleoflow (Calder et al. 2005) and to the onset of rapid salt withdrawal from beneath the Athol Syncline minibasin (Waldron and Rygel 2005). We attribute this change to the progradation of a megafan-like wedge of sediment from the Caledonia Highlands that caused differential loading, trapping of coarse-grained clastics in proximal areas, rapid salt withdrawal, and pronounced uplift of the Minudie Anticline diapir. The combination of subsidence in the Athol Syncline and uplift of the Minudie Anticline may have caused a short-lived reversal of paleoflow in this part of the basin. When halokinetic subsidence exceeds the rate of sediment supply, actively rising diapirs can develop tens to hundreds of metres of topographic relief and deflect nearby fluvial systems (Al-Zoubi and ten Brink 2001; Banham and Mountney 2013, 2014). Sediment dispersal eventually returned to a southeasterly pattern as salt withdrawal slowed, the crest of the diapir returned to a subtle paleotopographic high, and the locus of salt withdrawal progressively shifted toward Springhill in the east (Waldron et al. 2013).

\section{Paleoclimate}

Each member of the Boss Point Formation records a discrete paleoclimate phase developed during the transition from an arid/semi-arid climate in the late Mississippian to the relatively humid conditions that allowed expansion of peat-forming mires in the Lower Pennsylvanian Joggins and Springhill Mines formations (Calder 1998; Allen et al. 2011; Allen et al. 2013).

The basal Chignecto Bay Member is composed almost exclusively of redbeds with scattered caliche nodules, pedogenic structures, and thin limestones with desiccation cracks. Carbonized roots, greenish-grey bands, and discontinuous green mottles are rare. The reddish-brown color by itself is not a reliable indicator of paleoclimate as it only indicates oxidizing conditions for part of the year and 
could have formed under arid to semi-arid climates, as well as in areas with a humid climate and a modest dry season or well-drained paleotopographic highs (Sheldon 2005; Rygel et al. 2014). The Boss Point Formation is the only Pennsylvanian unit in the Joggins section that contains abundant, well developed calcareous paleosols. Development of significant amounts of pedogenic carbonate generally requires $<750$ $\mathrm{mm} / \mathrm{yr}$ of precipitation, a pronounced dry season, and prolonged periods (centuries to millennia) of undisturbed soil formation (Retallack 2008). The development of these paleosols throughout the Boss Point Formation and their scarcity in overlying formations is likely caused by relatively modest subsidence and halokinesis during deposition of the Boss Point Formation, a hypothesis supported by regional seismic data (Waldron et al. 2013) and comparison with other salt-influenced basins (Banham and Mountney 2013, 2014). Their presence also supports our hypothesis that the Boss Point Formation may represent considerably more time than the Little River, Joggins, and Springhill Mines formations; each of these calcareous paleosols could be equivalent to the amount of time represented by tens of metres of section in overlying units.

The Ward Point Member preserves a diverse assemblage of facies and potential paleoclimate indicators. The upward trend in fluvial style was interpreted to reflect a change from perennial to more seasonal flow conditions (Allen et al. 2013). Many well-drained occurrences in this interval contain pedogenic slickensides, mud aggregates (Gardiner 2005), and caliche nodules, suggesting seasonal variations in precipitation. The presence of thin coals, lycopsid rhizomorphs, and greenish-grey mudrocks indicates that, at least locally, mires and clastic swamps persisted long enough to allow for lycopsid growth and limited peat accumulation. The absence of growth rings in cordaitalean logs (Falcon-Lang and Scott 2000) is also consistent with a perennial water supply. The availability of water reflects local drainage conditions, which may or may not be a function of paleoclimate (Beuthin and Blake 2002). Although the transition between poorly drained and well-drained deposits could be caused by changes in climate, local differences in drainage conditions are considered as a more likely explanation. Retallack (2008) noted that, even under modest precipitation values (250-1300 mm of precipitation/ yr), soils with carbonate and gypsum can form in well drained areas while thin, high-ash peats form in adjacent coastal or lacustrine areas. Similar facies juxtapositions have also been reported from the Mississippi River delta (1110 to $1700 \mathrm{~mm}$ of precipitation/yr), where calcium-carbonate nodules form in well-drained areas adjacent to peat-forming wetlands (Roberts et al. 1981). Regardless of exact amount, the rainfall had to be sufficient to sustain scattered wetland habitats on a floodplain that was otherwise densely forested by cordaitalean trees, yet seasonal enough to allow for the periodic development of calcareous paleosols.
The transition from the Ward Point Member to the North Reef Member is marked by a shift to almost exclusively sandstone-rich, well-drained deposits in overbank areas and a change in fluvial style. Fielding et al. (2011) and Allen et al. (2013) interpreted the increased abundance of upperflow-regime structures within channel bodies as recording a change from (sub-)humid to semi-arid climate. Ielpi et al. (2014) interpreted the increased abundance of overbank sandstones as recording more arid conditions with intensified seasonal flow. Calcareous paleosols are present, but less abundant than in underlying strata, a change that could reflect the start of higher sedimentation rates associated with the onset of major halokinesis (Waldron et al. 2013).

\section{Stratigraphic Architecture \\ Cyclicity}

Detailed examination of the type section reveals that the fine-grained intervals contain considerably more floodplain deposits than suggested by the regional studies of Plint and Browne (1994) and Browne and Plint (1994). Given that the cyclic alternations between thick fluvial sandstones and fine-grained deposits in the Ward Point Member can be correlated regionally, their "lacustrine" flooding interpretation may be valid and the abundance of floodplain deposits a local anomaly. Plint and Browne (1994) interpreted the sharp, nonerosive contact between "lacustrine" and fluvial facies as evidence of rapid flooding caused by several metres of downdrop along basin-bounding faults. Although the formation was deposited during a phase of high-amplitude glacioeustasy and contains "brackish" limestones comparable to those described in younger units (Tibert and Dewey 2006; Rygel et al. 2008; Grey et al. 2011), the overwhelming influence of tectonism in the Cumberland Basin makes it difficult to confidently and unequivocally attribute the observed cyclicity to glacioeustatic fluctuations (Plint and Browne 1994; Calder 1994; Gibling and Rygel 2008).

Information about the nature and initiation of overbank and open water sedimentation is recorded by facies transitions within these finer-grained intervals. The following observations from Fig. 5 and Appendix 2 are particularly relevant:

- Megacycles 2, 4, 5, 6, 10, 12, and 16 have well exposed fine-grained floodplain intervals that lack open-water intervals and are composed only of poorly drained and well-drained deposits.

- Open-water intervals at the base of megacycles 1 and 3 sharply overlie multistorey sandstones in a way consistent with the rapid flooding events interpreted by Browne and Plint (1994). 
- Open-water intervals in megacycles 10 and $13 / 14$ occur atop floodplain deposits, suggesting more gradual flooding of the basin. Interbedded openwater and poorly drained deposits at the base of megacycle 15 also suggest gradual flooding and fluctuations in water depth.

- Open-water intervals are overlain by both poorly drained (megacycles 13/14) and well-drained deposits (megacycle 1 and $951.7 \mathrm{~m}$ ). Where openwater deposits are absent, there is no systematic relationship between poorly drained and welldrained deposits (megacycles 2, 3, 4, 5, and 6). These relationships suggest that there is not necessarily a systematic, Walther's Law-type progression from open-water to poorly drained to well-drained facies associations. These features may indicate an underfilled nature for some of the open-water bodies (Ielpi 2013).

- Relationships between open-water intervals and floodplain deposits cannot be determined where open-water units are erosionally overlain by multistorey sandstones (megacycles 3 and 10).

These relationships suggest that, at the type section, only some of the Boss Point megacycles record direct evidence of flooding and that these events could have been either rapid (megacycles 1 and 3) or gradual (megacycles $10,13 / 14$, and 15). Open-water intervals are overlain by both poorly drained and well-drained deposits, suggesting that there was not always a substantial wetland area flanking the shoreline and that open-water sedimentation ceased by infilling of the lake and progradation of a muddy shoreline.

Megacycles with only fine-grained terrestrial deposits may record an updip expression of the open-water flooding events. Because the type section was deposited on the flank of the Minudie Anticline, it may have occupied a subtle paleotopographic high that was inundated only by the largest flooding events or that was syndepositionally uplifted by diapirism as fluvial sediment prograded into the basin (Coleman 1988; Davison et al. 2000). Although it is possible that some poorly drained and well-drained deposits may represent pedogenically modified open water deposits, we consider it unlikely that all evidence of open water conditions would have been routinely and completely destroyed in overbank sediments that commonly contain primary textures, colors, and organic material. As mentioned above, it is unclear whether the difference between poorly drained and well-drained facies records local drainage conditions, paleoclimate, or some combination of the two.

\section{Overbank deposits}

Crevasse-splay sandstones make up less than $~ 10 \%$ of the thickness of overbank deposits below $781 \mathrm{~m}$ and
$30-50 \%$ of their thickness above this level. Although this pattern may correspond to increased seasonality (Ielpi et al. 2014), the sandstone-rich overbank motif is also typical of overbank deposits in the Joggins and Springhill Mines formations, which were deposited in a more humid, less seasonal climate (Allen et al. 2013). Given this observation, it is equally probable that sandstone-rich overbank deposits represent "normal" floodplain sedimentation patterns during high subsidence periods.

\section{Boss Point-Little River transition}

In addition to previously described changes in paleoflow, the North Reef Member represents a transition between the cyclic deposition of the underlying Ward Point Member and the uniform redbeds of the overlying Little River Formation. In terms of fluvial style, the North Reef and South Reef channel bodies represent a midpoint between the thick, abundant, regionally extensive multistorey fluvial sandstones of the Boss Point Formation and the thinner, isolated, more ribbon-like channel bodies of the Little River Formation (Calder et al. 2005; Fielding et al. 2011; Allen et al. 2013). Fine-grained deposits in the North Reef member consist only of sandstone-rich well-drained deposits.

Calder (1998) noted that this transition could be broadly traced across the Maritimes Basin and attributed it to changes driven by both tectonism and climate. Fielding et al. (2011) and Allen et al. (2013) documented a progressive increase in the abundance of upper flow regime structures in fluvial sandstones of the Boss Point Formation. Both sets of authors interpreted the abundance of these structures as recording a change from a humid to a semi-arid climate. Such a change would have allowed vegetative cover to persist while decreasing runoff and producing an overall decrease in sediment supply and corresponding increase in accommodation/sediment supply (Fielding et al. 2011; Allen et al. 2013). The North Reef and South Reef channel bodies may represent very short term anomalies wherein pulses of sediment were delivered to the basin, perhaps due to periods of marked decrease in vegetative cover caused by fire and/or drought (Falcon-Lang 1998, 1999, 2000).

Intensive halokinesis may have begun during deposition of the North Reef Member (Waldron and Rygel 2005; Waldron et al. 2013), a process that would have increased the ratio of accommodation to sediment supply and favored the shift to isolated channel bodies encased in overbank fines (Shanley and McCabe 1994; Banham and Mountney 2014). This transition was probably diachronous across the Cumberland Basin, as the locus of salt withdrawal would have shifted progressively away from basin margin areas as alluvial fans built further into the basin. 


\section{CONCLUSIONS}

In this paper we provide the first comprehensive account of the entirety of the $1125 \mathrm{~m}$ thick type section of the Boss Point Formation in the Joggins Fossil Cliffs UNESCO World Heritage Site. These strata can be divided into the major channel body (CB), open water (OW), poorly drained (PD), and well drained (WD) facies associations.

The Chignecto Bay Member (0-91.5 m) was excluded from several previous studies of the Boss Point Formation. This unit was deposited in a semi-arid climate and is largely composed of sandstone-poor, well-drained deposits with scattered caliche nodules and thin floodplain limestones. The two major channel bodies in this interval are both composed of a single storey and record a relatively simple cut-and-fill history.

The Ward Point Member (91.5-951.7 m) is composed of numerous alternations between thick multistorey channel bodies and finer-grained open-water, poorly drained and well-drained floodplain deposits. We interpret these floodplain deposits as having formed under a subhumid climate, either beneath well-drained forest soils or poorly drained, localized wetlands. Open-water deposits are composed of laminated dark mudrocks and limestones that formed during flooding of the basin. Some open-water intervals contain ostracod-bearing, organic-rich limestones similar to those described in the overlying Joggins Formation (Tibert and Dewey 2006; Grey et al. 2011) and may represent deposition in brackish bays or lagoons.

The North Reef member (951.7-1125 m) is composed of sandstone-rich, well-drained deposits and two major channel bodies. It records increased seasonality and/ or aridity and represents a transition between the cyclic architecture of the underlying Ward Point Member and the isolated channel bodies and redbeds of the overlying Little River Formation.

Detailed analysis of the type section reveals a much higher percentage of floodplain deposits than suggested by the regional studies of Browne and Plint (1994) and Plint and Browne (1994). We attribute this difference to the type section's position on the slightly elevated flank of the salt-cored Minudie Anticline. The influence of this syndepositional structure explains changes in facies architecture as well as paleoflow anomalies above, below, and within the Boss Point Formation.

\section{ACKNOWLEDGEMENTS}

M. Rygel acknowledges the donors of the American Chemical Society Petroleum Research Fund (PRF Grant \#47967-GB8), a sabbatical from SUNY Potsdam, and field assistance by A. Brewer. C. Lally was supported by a Kilmer Undergraduate Research Apprenticeship from
SUNY Potsdam. M. Gibling and A. Ielpi were supported by a Discovery Grant to MG from the Natural Sciences and Engineering Research Council of Canada (NSERC). A. Bashforth was supported by a Postdoctoral Fellowship from NSERC. We thank Brian Hebert for discussion and logistical assistance. We also thank the Joggins Fossil Institute and Nova Scotia Museum for their assistance and for supporting our applications for Heritage Research Permits. P.J. Wagner of the Smithsonian Institution in Washington, D.C., provided provisional identification of Strobeus. Suggestions by Howard Falcon-Lang, Rob Fensome, and an anonymous reviewer greatly improved this manuscript.

\section{REFERENCES}

Al-Zoubi, A. and ten Brink, U.S. 2001. Salt diapirs in the Dead Sea basin and their relationship to Quaternary extensional tectonics. Marine and Petroleum Geology, 18, pp. 779-797. http://dx.doi.org/10.1016/S02648172(01)00031-9

Allen, J., Fielding, C.R., Gibling, M.R., and Rygel, M.C. 2011. Fluvial response to paleo-equatorial climate fluctuations during the late Paleozoic Ice Age. Geological Society of America Bulletin, 128, pp. 1524-1538. http://dx.doi. org/10.1130/B30314.1

Allen, J.P., Fielding, C.R., Rygel, M.C., and Gibling, M.R. 2013. Deconvolving signals of tectonic and climatic controls from continental basins: an example from the late Palaeozoic Cumberland Basin, Nova Scotia. Journal of Sedimentary Research, 83, pp. 847-872. http://dx.doi. org/10.2110/jsr.2013.58

Álvarez-Vázquez, C. and Wagner, R.H. 2014. Lycopsida from the lower Westphalian (Middle Pennsylvanian) of the Maritime Provinces, Canada. Atlantic Geology, 50, pp. 167-232. http://dx.doi.org/10.4138/atlgeol.2014.011

Banham, S.G. and Mountney, N.P. 2013. Evolution of fluvial systems in salt-walled mini-basins: a review and new insights. Sedimentary Geology, 296, pp. 142-166. http:// dx.doi.org/10.1016/j.sedgeo.2013.08.010

Banham, S.G. and Mountney, N.P. 2014. Climatic versus halokinetic control on sedimentation in a dryland fluvial succession. Sedimentology, 61, pp. 570-608. http://dx.doi. org/10.1111/sed.12064

Bashforth, A.R., Drábková, J., Opluštil, S., Gibling, M.R., and Falcon-Lang, H.J. 2011. Landscape gradients and patchiness in riparian vegetation on a Middle Pennsylvanian braided-river plain prone to flood disturbance (Nýřany Member, central and western Bohemian Basin, Czech Republic). Review of Palaeobotany and Palynology, 163, pp. 153-189. http:// dx.doi.org/10.1016/j.revpalbo.2010.10.001

Bashforth, A.R., Cleal, C.J., Gibling, M.R., Falcon-Lang, H.J., and Miller, R.F. 2014. Paleoecology of Early Pennsylvanian 
vegetation on a seasonally dry tropical landscape (Tynemouth Creek Formation, New Brunswick, Canada). Review of Palaeobotany and Palynology, 200, pp. 229263. http://dx.doi.org/10.1016/j.revpalbo.2013.09.006

Bell, W.A. 1914. Joggins Carboniferous section, Nova Scotia. Geological Survey of Canada, Summary Report for 1912, pp. 360-371.

Bell, W.A. 1943. Carboniferous rocks and fossil floras of northern Nova Scotia. Geological Survey of Canada, Memoir 238, $277 \mathrm{p}$.

Belt, E.S. 1964. Revision of Nova Scotia middle Carboniferous units. American Journal of Science, 262, pp. 653-673. http://dx.doi.org/10.2475/ajs.262.5.653

Beuthin, J.D. and Blake, B.M. 2002. Scrutiny of a global climate model for Upper Mississippian depositional sequences in the central Appalachian foreland basin, USA. Journal of Geology, 110, pp. 739-747. http://dx.doi. org/10.1086/342867

Boon, J. and Calder, J.H. 2007. Nomination of the Joggins Fossil Cliffs for Inscription on the World Heritage List. Cumberland Regional Economic Development Association, Amherst, Nova Scotia, 129 p. http://whc. unesco.org/uploads/nominations/1285.pdf

Briggs, D.E.G., Plint, A.G., and Pickerill, R.K. 1984. Arthropleura trails from the Westphalian of eastern Canada. Palaeontology, 27, pp. 843-855.

Bristow, C.S. 1993. Sedimentary structures exposed in bar tops in the Brahmaputra River, Bangladesh. In Braided rivers. Edited by J.L. Best and J.L. Bristow. Geological Society Special Publication 75, pp. 277-289.

Browne, G. 1991. The sedimentology of the Boss Point Formation (Pennsylvanian), eastern New Brunswick and northern Nova Scotia. Unpublished Ph.D. thesis, University of Western Ontario, London, Ontario, 552 p.

Browne, G. and Kingston, D. 1993. Early diageneticspherulitic siderites from Pennsylvanian palaeosols in the Boss Point Formation, Maritime Canada. Sedimentology, 40, pp. 467-474. http://dx.doi.org/10.1111/j.1365-3091.1993. tb01346.x

Browne, G.H. and Plint, A.G. 1994. Alternating braided fluvial and lacustrine deposition in a strike-slip setting: the Pennsylvanian Boss Point Formation of the Cumberland Basin, Maritime Canada. Journal of Sedimentary Research, B64, pp. 40-59.

Cabrera, L. and Sáez, A. 1987. Coal deposition in carbonaterich shallow lacustrine systems: the Calaf and Mequinenza sequences (Oligocene, eastern Ebro Basin, NE Spain). Journal of the Geological Society, 144, pp. 451-461. http://dx.doi.org/10.1144/gsjgs.144.3.0451

Calder, J.H. 1994. The impact of climate change, tectonism and hydrology on the formation of Carboniferous tropical intermontane mires: the Springhill coalfield, Cumberland Basin, Nova Scotia. Palaeogeography, Palaeoclimatology, Palaeoecology, 106, pp. 323-351. http://dx.doi. org/10.1016/0031-0182(94)90017-5
Calder 1998. The Carboniferous evolution of Nova Scotia. In Lyell, the past is the key to the present. Edited by D.J. Blundell and A.C. Scott. Geological Society of London, Special Publication 143, pp. 261-302.

Calder, J.H., Rygel, M.C., Hebert, B.L., and Falcon-Lang, H.J. 2005. Sedimentology and stratigraphy of Pennsylvanian red beds near Joggins, Nova Scotia: The proposed Little River Formation with redefinition of the Joggins Formation. Atlantic Geology, 41, pp. 143-167.

Calder, J.H., Gibling, M.R., Scott, A.C., Davies, S.J., and Hebert, B.L. 2006. Paleoecology and sedimentology of a fossil lycopsid forest succession in the classic Pennsylvanian section at Joggins, Nova Scotia. In Wetlands through time. Edited by S.F. Greb and W.A. DiMichele. Geological Society of America, Special Publication 399, pp. 169-195.

Cant, D.J. and Walker, R.G. 1978. Fluvial processes and facies sequences in the sandy braided South Saskatchewan River, Canada. Sedimentology, 25, pp. 625-648. http:// dx.doi.org/10.1111/j.1365-3091.1978.tb00323.x

Caudill, M.R., Driese, S.G., and Mora, C.I. 1996. Preservation of a paleo-vertisol and an estimate of Late Mississippian paleoprecipitation. Journal of Sedimentary Research, 66, pp. 57-78.

Coleman, J.M. 1988. Dynamic changes and processes in the Mississippi River delta. Geological Society of America Bulletin, 100, pp. 999-1015. http://dx.doi. org/10.1130/0016-7606(1988)100<0999:DCAPIT>2.3. $\mathrm{CO} ; 2$

Copeland, M.J. 1959. Coalfields, west half Cumberland County, Nova Scotia. Geological Survey of Canada, Memoir 298, 89 p.

Davies, S.J. and Gibling, M.R. 2003. Architecture of coastal and alluvial deposits in an extensional basin: the Carboniferous Joggins Formation of eastern Canada. Sedimentology, 50, pp. 415-439. http://dx.doi. org/10.1046/j.1365-3091.2003.00553.x

Davies, S.J., Gibling, M.R., Rygel, M.C., Calder, J.H., and Skilliter, D.M. 2005. The Joggins Formation: stratigraphic framework and sedimentological log of the historic fossil cliffs. Atlantic Geology, 41, pp. 115-142.

Davison, I., Alsop, G., Evans, N., and Safaricz, M. 2000. Overburden deformation patterns and mechanisms of salt diapir penetration in the Central Graben, North Sea. Marine and Petroleum Geology, 17, pp. 601-618. http:// dx.doi.org/10.1016/S0264-8172(00)00011-8

Demko, T. M. and Gastaldo, R.A. 1992. Paludal environments of the Mary Lee coal zone, Pottsville Formation, Alabama: stacked clastic swamps and peat mires. International Journal of Coal Geology, 20, pp. 23-47. http://dx.doi. org/10.1016/0166-5162(92)90003-F

DiMichele, W.A. and Phillips, T.L. 1994. Paleobotanical and paleoecological constrainsts on models of peat formation in the Late Carboniferous of Euramerica. Palaeogeography, 
Palaeoclimatology, Palaeoecology, 106, pp. 39-90. http:// dx.doi.org/10.1016/0031-0182(94)90004-3

DiMichele, W.A., Cecil, C.B., Monta-ez, I.P., and FalconLang, H.J. 2010. Cyclic changes in Pennsylvanian paleoclimate and effects on floristic dynamics in tropical Pangaea. International Journal of Coal Geology, 83, pp. 329-344. http://dx.doi.org/10.1016/j.coal.2010.01.007

DiVenere, V.J. and Opdyke, N.D. 1991. Magnetic polarity stratigraphy and Carboniferous paleopole positions from the Joggins section, Cumberland structural basin, Nova Scotia. Journal of Geophysical Research, 96, pp. 40514064. http://dx.doi.org/10.1029/90JB02148

Dolby, G., 1991. The palynology of the western Cumberland Basin, Nova Scotia. Nova Scotia Department of Mines and Energy, Open File Report 91-006, 39 p.

Dolby, G., 1994. Palynological analyses of Carboniferous outcrop and borehole samples from the NATMAP program, 1993 field season (Sections 5, 6, 7, 8, and 9). Geological Survey of Canada, Unpublished report 9303, $92 \mathrm{pp}$.

Falcon-Lang, H.J. 1998. The impact of wildfire on an Early Carboniferous coastal environment, North Mayo, Ireland. Palaeogeography, Palaeoclimatology, Palaeoecology, 139, pp. 121-138. http://dx.doi.org/10.1016/S00310182(97)00142-9

Falcon-Lang, H.J. 1999. Fire ecology of a Late Carboniferous floodplain, Joggins, Nova Scotia. Journal of the Geological Society, London, 156, pp. 137-148. http://dx.doi. org/10.1144/gsjgs.156.1.0137

Falcon-Lang, H.J. 2000. Fire ecology of the Carboniferous tropical zone. Palaeogeography, Palaeoclimatology, Palaeoecology, 164, pp. 339-355. http://dx.doi. org/10.1016/S0031-0182(00)00193-0

Falcon-Lang, H.J. 2003. Late Carboniferous tropical dryland vegetation in an alluvial-plain setting, Joggins, Nova Scotia, Canada. Palaios, 18, pp. 197-211. http://dx.doi. org/10.1669/0883-1351(2003)018<0197:LCTDVI >2.0. $\mathrm{CO} ; 2$

Falcon-Lang, H.J. 2005. Small cordaitalean trees in a marine-influenced coastal habitat in the Pennsylvanian Joggins Formation, Nova Scotia. Journal of the Geological Society, 162, pp. 485-500. http://dx.doi.org/10.1144/0016764904-080

Falcon-Lang, H.J. 2009. Earliest history of coal mining and grindstone quarrying at Joggins, Nova Scotia, and its implications for the meaning of the place name "Joggins". Atlantic Geology, 45, pp. 1-20. http://dx.doi.org/10.4138/ atlgeol.2009.001

Falcon-Lang, H.J. and Scott, A.C. 2000. Upland ecology of some Late Carboniferous cordaitalean trees from Nova Scotia and England. Palaeogeography, Palaeoclimatology, Palaeoecology, 156, pp. 225-242. http://dx.doi. org/10.1016/S0031-0182(99)00142-X

Falcon-Lang, H.J., Rygel, M.C., Gibling, M.R., and Calder, J.H. 2004. An early Pennsylvanian waterhole deposit and its fossil biota in dryland alluvial plain setting, Joggins, Nova Scotia. Journal of the Geological Society, London, 161, pp. 209-222. http://dx.doi.org/10.1144/0016764903-109

Falcon-Lang, H.J., Benton, M.J., Braddy, S.J., and Davies, S.J. 2006. The Pennsylvanian tropical biome reconstructed from the Joggins Formation of Nova Scotia, Canada. Journal of the Geological Society, 163, pp. 561-576. http://dx.doi.org/10.1144/0016-764905-063

Falcon-Lang, H.J., Nelson, W.J., Elrick, S., Looy, C.V., Ames, P.R., and DiMichele, W.A. 2009. Incised channel fills containing conifers indicate that seasonally dry vegetation dominated Pennsylvanian tropical lowlands. Geology, 37, pp. 923-926. http://dx.doi.org/10.1130/G30117A.1

Fielding, C.R., Allen, J.P., Alexander, J., Gibling, M.R., Rygel, M.C., and Calder, J.H. 2011. Fluvial systems and their deposits in hot, seasonal semi-arid and sub-humid settings; modern and ancient examples. In From river to rock record; the preservation of fluvial sediments and their subsequent interpretation. Edited by S.K. Davidson, S. Leleu, and C.P. North. Society for Sedimentary Geology (SEPM), Special Publication 97, pp. 89-111.

Gardiner, J. 2005. Pedogenic mud aggregates in Pennsylvanian strata near Joggins, Nova Scotia. Unpublished B.Sc. Honors thesis. Dalhousie University, Halifax, Nova Scotia, 116 p.

Gastaldo, R.A. 1987. Confirmation of Carboniferous clastic swamp communities. Nature, 326, pp. 869-871. http:// dx.doi.org/10.1038/326869a0

Gastaldo, R.A. 1992. Regenerative growth in fossil horsetails following burial by alluvium. Historical Biology, 6, pp. 203-219. http://dx.doi.org/10.1080/10292389209380429

Gibling, M.R. 2006. Width and thickness of fluvial channel bodies and valley fills in the geological record: a literature compilation. Journal of Sedimentary Research, 76, pp. 731-770. http://dx.doi.org/10.2110/jsr.2006.060

Gibling, M.R. and Rygel, M.C. 2008. Late Paleozoic cyclic strata of Euramerica: recognition of Gondwanan glacial signatures during periods of thermal subsidence. In Resolving the Late Paleozoic Ice Age in time and space. Edited by C.R. Fielding, T.D. Frank, T.D., and J.L. Isbell. Geological Society of America, Special Publication 441, pp. 219-233.

Gibling, M.R., Calder, J.H., Ryan, R.J., van de Poll, H.W., and Yeo, G.M. 1992. Late Carboniferous and Early Permian drainage patterns in Atlantic Canada. Canadian Journal of Earth Sciences, 29, pp. 338-352. http://dx.doi. org/10.1139/e92-030

Gibling, M.R., Culshaw, N., Rygel, M.C., and Pascucci, V. 2008. The Maritimes Basin of Atlantic Canada: basin creation and destruction in the collisional zone of Pangea. In The Phanerozoic sedimentary basins of the United States and Canada. Edited by A.D. Miall. Elsevier, Amsterdam, pp. 211-244. http://dx.doi.org/10.1016/ S1874-5997(08)00006-3 
Gierlowski-Kordesch, E.H., and Gibling, M.R. 2002. Pedogenic mud aggregates in rift sedimentation. In Sedimentation in continental rifts. Edited by G.M. Ashley and R. Renaut. Society for Sedimentary Geology (SEPM), Special Publication 73, pp. 195-206.

Giles, P.S. and Utting, J. 1999. Maritimes Basin stratigraphy - Prince Edward Island and adjacent Gulf of St. Lawrence. Geological Survey of Canada, Open File 3732, unpaginated cross-section.

Godin, P.D. 1991. Fining-upward cycles in the sandy braided-river deposits of the Westwater Canyon Member (Upper Jurassic), Morrison Formation, New Mexico. Sedimentary Geology, 70, pp. 61-82. http://dx.doi. org/10.1016/0037-0738(91)90066-M

Gradstein, F.M., Ogg, J.G., and Schmitz, M., 2012, The geologic time scale 2012 (2-volume set): Waltham, MA, Elsevier, $1144 \mathrm{p}$.

Grey, M., Pufahl, P.K., and Aziz, A.A. 2011. Using multiple environmental proxies to determine degree of marine influence and paleogeographical position of the Joggins Fossil Cliffs, UNESCO World Heritage Site. Palaios, 26, pp. 256-263. http://dx.doi.org/10.2110/palo.2010.p10$118 \mathrm{r}$

Grey, M., Finkel, Z.V., Pufahl, P.K., and Reid, L.M. 2012. Evolutionary mode of the ostracod, Velatomorpha altilis, from the Joggins Fossil Cliffs UNESCO World Heritage Site. Lethaia, 45, pp. 615-623. http://dx.doi.org/10.1111/ j.1502-3931.2012.00328.x

Gurnell, A.M., Petts, G.E., Hannah, D.M., Smith, B.P., Edwards, P.J., Kollmann, J., Ward, J.V., and Tockner, K. 2001. Riparian vegetation and island formation along the gravel-bed Fiume Tagliamento, Italy. Earth Surface Processes and Landforms, 26, pp. 31-62. http:// dx.doi.org/10.1002/1096-9837(200101)26:1<31::AIDESP155>3.0.CO;2-Y

Hamblin, A.P. 2001. Stratigraphy, sedimentology, tectonics, and resource potential of the Lower Carboniferous Mabou Group, Nova Scotia. Ottawa, Geological Survey of Canada, Bulletin 568, 164 p. http://dx.doi.org/10.4095/212926

Hibbard, J. and Waldron, J.W.F. 2009. Truncation and translation of Appalachian promontories: mid-Paleozoic strike-slip tectonics and basin initiation. Geology, 37, pp. 487-490. http://dx.doi.org/10.1130/G25614A.1

Holbrook, J. 2001. Origin, genetic interrelationships, and stratigraphy over the continuum of fluvial channelform bounding surfaces: an illustration from middle Cretaceous strata, southeastern Colorado. Sedimentary Geology, 144, pp. 179-222. http://dx.doi.org/10.1016/ S0037-0738(01)00118-X

Horn, J.D., Fielding, C.R., and Jeockel, R.M. 2012. Revision of Platte River alluvium facies model through observations of extant channels and barforms, and subsurface alluvial valley fills. Journal of Sedimentary Research, 82, pp. 7291. http://dx.doi.org/10.2110/jsr.2012.9
Howie, R.D. and Barss, M.S. 1975. Paleogeography and sedimentation in the upper Paleozoic, eastern Canada. In Canada's continental margins and offshore petroleum exploration. Edited by C.J. Yorath, E.R. Parker, and D.J. Glass. Canadian Society of Petroleum Geologists, Memoir 4, pp. 45-57.

Ielpi, A. 2013. Frequency-reliant corretive patterns of asymmetric lacustrine-paralic sequences: a genetic approach to the late Miocene Bithynia Marlstones of the southeastern Volterra Basin. Journal of Sedimentary Research, 83, pp. 377-394. http://dx.doi.org/10.2110/ jsr.2013.31

Ielpi, A., Gibling, M.R., Bashforth, A., Lally, C., Rygel, M.C., and Al-Silwadi, S. 2014. Role of vegetation in shaping Early Pennsylvanian braided rivers: architecture of the Boss Point Formation, Atlantic Canada. Sedimentology. http://dx.doi.org/10.1111/sed.12109

Kelley, D.G. 1967. Some aspects of Carboniferous stratigraphy and depositional history in the Atlantic Provinces. In Collected papers on geology of the Atlantic region: Hugh Lilly Memorial Volume. Edited by E.R.W. Neale and H. Williams. Geological Association of Canada, Special Paper 4, pp. 213-228.

Keppie, J.D. 2006. Digital version of Nova Scotia Department of Natural Resources Map ME 2000-1, geological map of the Province of Nova Scotia: Halifax, Nova Scotia, Nova Scotia Department of Natural Resources, 1:500 000 scale.

Kraus, M.J., and Wells, T.M. 1999. Recognizing avulsion deposits in the ancient stratigraphic record. In Fluvial sedimentology VI. Edited by N.D. Smith and J. Rogers. International Association of Sedimentologists, Special Publication 28, pp. 251-268.

Logan, W. E. 1845. A section of the Nova Scotia coal measures as developed at Joggins on the Bay of Fundy, in descending order, from the neighbourhood of the west Ragged Reef to Minudie, reduced vertical thickness. In Logan, W.E. Appendix W: Geological Survey. Journals of the Legislative Assembly of the Province of Canada, 1844-5, v. 4, pp. W29-W45. http://www.canadiana.org/ ECO/PageView/9_00955_4_1/0554?id=47cfc978690d6 $0 \mathrm{c7}$

Machette, M.N. 1985. Calcic soils of the southwestern United States. In Soils and Quaternary geology of the southwestern United States. Edited by D.L. Weide. Geological Society of America, Special Paper 203, pp. $1-21$.

Manheim, F.T. and Hayes, L., 2002, Lake Pontchartrain Basin: bottom sediments and related environmental resources. U.S. Geological Survey Professional Paper, US Department of the Interior, unpaginated. http://pubs. usgs.gov/pp/p1634j/index.htm

McLeod, J.R. 2010. Paleoenvironmental and tectonostratigraphic evolution of the west Cumberland Basin of Nova Scotia and New Brunswick during the 
Upper Mississippian. Unpublished M.Sc. thesis, St. Mary's University, Halifax, Nova Scotia, 109 p.

Miall, A.D. 1988. Architectural elements and bounding surfaces in fluvial deposits: anatomy of the Kayenta Formation (Lower Jurassic), southwest Colorado. Sedimentary Geology, 55, pp. 233-262. http://dx.doi. org/10.1016/0037-0738(88)90133-9

Miall, A.D. 1996. The geology of fluvial deposits. Springer, Berlin. $582 \mathrm{p}$.

Miall, A.D. 2006. The Geology of Fluvial Deposits. Berlin, Springer, $582 \mathrm{p}$.

Monta-ez, I.P. and Cecil, C.B. 2013. Paleoenvironmental clues archived in non-marine Pennsylvanian-lower Permian limestones of the central Appalachian Basin, USA. International Journal of Coal Geology, 119, pp. 4155. http://dx.doi.org/10.1016/j.coal.2013.08.009

Müller, R., Nystuen, J.P., and Wright, V.P. 2004. Pedogenic mud aggregates and paleosol development in ancient dryland river systems: criteria for interpreting alluvial mudrock origin and floodplain dynamics. Journal of Sedimentary Research, 74, pp. 537-551. http://dx.doi. org/10.1306/010704740537

Nance, R.D. 1987. Dextral transpression and Late Carboniferous sedimentation in the Fundy coastal zone of southern New Brunswick. In Sedimentary basins and basin-forming mechanisms. Edited by C. Beaumont and A.J. Tankard. Canadian Society of Petroleum Geologists, Memoir 12, pp. 363-377.

New Brunswick Department of Natural Resources and Energy. 2000. Bedrock geology of New Brunswick. New Brunswick Minerals and Energy Division, Map NR-1, 1:500 000 scale.

Opdyke, N.D., Giles, P.S., and Utting, J. 2014. Magnetic polarity stratigraphy and palynostratigraphy of the Mississippian-Pennsylvanian boundary interval in eastern North America and the age of the beginning of the Kiaman. Geological Society of America Bulletin. http://dx.doi.org/10.1130/B30953.1

Pfefferkorn, H.W., Archer, A.W., and Zodrow, E.L. 2001. Modern tropical analogs for Carboniferous standing forests: comparison of extinct Mesocalamites with extant Montrichardia. Historical Biology, 15, pp. 235-250. http:// dx.doi.org/10.1080/10292380109380595

Phillips, T.L. and DiMichele, W.A. 1992. Comparative ecology and life-history biology of arborescent lycopsids in Late Carboniferous swamps of Euramerica. Annals of the Missouri Botanical Garden, 79, pp. 560-588. http:// dx.doi.org/10.2307/2399753

Plint, A.G. and Browne, G.H. 1994. Tectonic event stratigraphy in a fluvio-lacustrine, strike-slip setting: the Boss Point Formation (Westphalian A), Cumberland Basin, Maritime Canada. Journal of Sedimentary Research, B64, pp. 341-364.

Rehill, T.A. 1996. Late Carboniferous nonmarine sequence stratigraphy and petroleum geology of the central
Maritimes Basin, Eastern Canada. Unpublished Ph.D. thesis. Dalhousie University, Halifax, Nova Scotia, 406 p.

Retallack, G.J. 2001. Soils of the past. Blackwell, Ames, Iowa, 404 p. http://dx.doi.org/10.1002/9780470698716

Retallack, G.J. 2008. Soils of the past: An introduction to paleopedology. Malden, MA, John Wiley \& Sons, 512 p.

Roberts, H.H., Wells, J.T., and Kahn, J.H. 1981. Alluvial valley and upper deltaic plain: a guidebook for AASP field trip, October, 1981. American Association of Stratigraphic Palynologists, Houston, Texas, 23 p.

Rust, B.R. and Nanson, G.C. 1989. Bedload transport of mud as pedogenic aggregates in modern and ancient rivers. Sedimentology, 36, pp. 291-306. http://dx.doi. org/10.1111/j.1365-3091.1989.tb00608.x

Ryan, R.J. 1985. Upper Carboniferous strata of the Tatamagouche Syncline, Cumberland Basin, Nova Scotia. Geological Survey of Canada, Current Research Part B, pp. 481-490.

Ryan, R.J. and Boehner, R.C. 1994. Geology of the Cumberland Basin, Cumberland, Colchester and Pictou counties, Nova Scotia. Nova Scotia Department of Natural Resources, Memoir 10, 222 p.

Ryan, R.J., Boehner, R.C., and Deal, A. 1990a. Cumberland Basin geology map, Apple River and Cape Chignecto, Cumberland County, Nova Scotia Department of Mines and Energy, Map 90-11, 1:50 000 scale.

Ryan, R.J., Boehner, R.C., Deal, A., and Calder, J.H., 1990b, Cumberland Basin geology map, Amherst, Springhill and Parrsboro, Cumberland County, Nova Scotia Department of Mines and Energy, Map 90-12, 1:50 000 scale.

Ryan, R.J., Boehner, R.C., and Calder, J.H. 1991. Lithostratigraphic revisions of the upper Carboniferous to lower Permian strata in the Cumberland Basin, Nova Scotia and the regional implications for the Maritimes Basin in Atlantic Canada. Bulletin of Canadian Petroleum Geology, 39, pp. 289-314.

Rygel, M.C. and Gibling, M.R. 2006. Natural geomorphic variability recorded in a high-accommodation setting: fluvial architecture of the Pennsylvanian Joggins Formation, Atlantic Canada. Journal of Sedimentary Research, 76, pp. 1230-1251. http://dx.doi.org/10.2110/ jsr.2006.100

Rygel, M.C. and Shipley, B.C. 2005. "Such a section as never was put together before": Logan, Dawson, Lyell, and midNineteenth-Century measurements of the Pennsylvanian Joggins section of Nova Scotia. Atlantic Geology, 41, pp. 87-102.

Rygel, M.C., Fielding, C.R., Frank, T.D., and Birgenheier, L.P. 2008. The magnitude of Late Paleozoic glacioeustatic fluctuations: a synthesis. Journal of Sedimentary Research, 78, pp. 500-511. http://dx.doi.org/10.2110/jsr.2008.058

Rygel, M.C., Sheldon, E.P., Stimson, M.R., Calder, J.H., Ashley, K.T., and Salg, J. 2014. The Pennsylvanian Springhill Mines Formation: sedimentological framework of a portion of the Joggins Fossil Cliffs UNESCO World 
Heritage Site. Atlantic Geology.

Shanley, K.W. and McCabe, P.J. 1994. Perspectives on the sequence stratigraphy of continental strata. American Association of Petroleum Geologists Bulletin, 78, pp. 544-568.

Sheldon, N.D. 2005. Do red beds indicate paleoclimatic conditions?: a Permian case study: Palaeogeography, Palaeoclimatology, Palaeoecology, 228, pp. 305-319. http://dx.doi.org/10.1016/j.palaeo.2005.06.009

Skilliter, D.M. 2001. Distal marine influence in the Forty Brine section, Joggins, Nova Scotia, Canada. Unpublished M.Sc. thesis, Boston College, Boston, 96 p.

St. Peter, C.J. and Johnson, S.C. 2009. Stratigraphy and structural history of the late Paleozoic Maritimes Basin in southeastern New Brunswick, Canada. New Brunswick Department of Natural Resources, Minerals Policy and Planning Division, Memoir 3, 348 p.

Tibert, N.E., and Dewey, C.P. 2006. Velatomorpha, a new healdioidean ostracode genus from the early Pennsylvanian Joggins Formation, Nova Scotia, Canada. Micropaleontology, 52, pp. 51-66. http://dx.doi. org/10.2113/gsmicropal.52.1.51

Tibert, N.E., Rygel, M.C., Saunder, S.C., Elrick, S.D., and Nelson, J.D. 2013. Temporal and spatial distribution of ostracodes across the Pennsylvanian-Permian boundary interval in eastern North America. International Journal of Coal Geology, 119, p. 93-105. http://dx.doi. org/10.1016/j.coal.2013.08.002

Tockner, K., Ward, J.V., Arscott, D.B., Edwards, P.J., Kollmann, J., Gurnell, A.M., Petts, G.E., and Maiolini, B. 2003. The Tagliamento River: a model ecosystem of European importance. Aquatic Sciences, 65, pp. 239-253. http://dx.doi.org/10.1007/s00027-003-0699-9

Utting, J. and Wagner, R.H., 2005, Megaflora of the Upper Carboniferous Cumberland Group, Joggins area, Nova Scotia and New Brunswick. GAC-MAC-CSPG-CSSS Joint Meeting - Abstracts, Halifax, Nova Scotia, pp. 197.

Utting, J., Giles, P.S., and Dolby, G. 2010. Palynostratigraphy of Mississippian and Pennsylvanian rocks, Joggins area, Nova Scotia and New Brunswick, Canada. Palynology, 34, pp. 43-89. http://dx.doi.org/10.1080/01916121003620569

Vasey, G.M. 1984. Westphalian macrofaunas in Nova Scotia: paleoecology and correlation. Unpublished Ph.D. Thesis, University of Strathclyde, Glasgow, Scotland, $467 \mathrm{p}$.

Wagner, E.E., Rygel, M.C., Hebert, B.L., and O'Brien, N.R. 2013. Pyritization of a Stigmaria from the Boss Point Formation (Pennsylvanian), Nova Scotia. Geological Society of America, Abstracts with Programs, 45, pp. 589.

Waldron, J.W.F. and Rygel, M.C. 2005. Role of evaporite withdrawal in the preservation of a unique coalbearing succession: Pennsylvanian Joggins Formation, Nova Scotia. Geology, 33, pp. 337-340. http://dx.doi. org/10.1130/G21302.1

Waldron, J.W.F., Rygel, M.C., Gibling, M.R., and Calder, J.H. 2013. Evaporite tectonics and the late Paleozoic stratigraphic development of the Cumberland Basin, Appalachians of Atlantic Canada. Geological Society of America Bulletin, 125, pp. 945-960. http://dx.doi. org/10.1130/B30718.1

Walker, T.R. 1967. Formation of red beds in modern and ancient deserts. Geological Society of America Bulletin, 78, pp. 353-368. http://dx.doi.org/10.1130/00167606(1967)78[353:FORBIM]2.0.CO;2

Webb, G.W. 1963. Occurrence and exploration significance of strike slip faults in southern New Brunswick, Canada. American Association of Petroleum Geologist Bulletin, 47, pp. 1904-1927.

Editorial responsibility: Robert A. Fensome

\section{APPENDIX 1}

Information required by the North American Stratigraphic Code for the formal naming of the North Reef Member of the Boss Point Formation.

\section{Intent, utility, and historical background}

Ryan et al. (1991) used the term "North Reef Member" in reference to the uppermost, redbed-dominated portion of the Boss Point Formation. Although never formally defined or described, this name also appears in several diagrams in Ryan and Boehner (1994).

On the Maringouin Peninsula of New Brunswick, which is less than $10 \mathrm{~km}$ from the type section, St. Peter and Johnson (2009) subdivided the Boss Point Formation into the redbed-dominated Chignecto Bay Member and the overlying braided fluvial/lacustrine strata of the Ward Point Member. Although Ryan et al.'s (1991) North Reef member was not specifically addressed or identified, St. Peter and Johnson (2009) mentioned that redbeds near the top of the type section might be correlative to the upper part of their Ward Point Member.

Detailed study of the type section and comparison with exposures of the Boss Point Formation in New Brunswick by St. Peter and Johnson (2009) demonstrate that this interval is sufficiently different from over- and underlying units to justify its designation as a formal member.

\section{Category, name, and rank}

The North Reef Member is a lithostratigraphic unit named for "North Reef", a thick sandstone that crops out in the intertidal zone north of Lower Cove, Nova Scotia at $45^{\circ} 43^{\prime} 37.46^{\prime \prime} \mathrm{N}, 64^{\circ} 26^{\prime} 31.53^{\prime \prime} \mathrm{W}$. Although it does not appear on modern topographic maps, no other appropriate names are available and this term features prominently in older literature and maps because this interval was extensively quarried for grindstones in the 1700s and 1800s (FalconLang 2009). 


\section{Type section}

The type section of the North Reef Member occurs between 951.7-1125 $\mathrm{m}$ in the type section of the Boss Point Formation (Fig. 3; Appendix 2).

\section{Unit description}

The North Reef Member contains thin sheet sandstones and channel bodies, red mudrocks with scattered green/ grey mottles and carbonate nodules, and thick channel bodies filled with stacked cosets of trough cross-beds and rare internal erosion surfaces. The North Reef Member is distinguished from the underlying Ward Point Member by the absence of thick green/grey mudrocks and limestones as well as the simpler, succession-dominated architecture of the channel bodies. It is distinguished from the overlying Little River Formation by the presence of $>10 \mathrm{~m}$ thick channel bodies filled almost exclusively with stacked cosets of trough cross-beds.

\section{Boundaries, correlation, and extent}

The boundary with the underlying Ward Point Member is placed atop the uppermost limestone or grey laminated mudrock assignable to the open water facies association, as described above. At the type section, it is the sharp contact between a grey laminated mudrock and red mudrock at $951.7 \mathrm{~m}$. The upper boundary is placed at the top of the uppermost thick $(>10 \mathrm{~m})$ channel body filled with stacked cosets of trough cross-beds as described above; at the type section this is at the top of "South Reef". Regional contacts with over- and underlying units are likely gradational to interbedded.

St. Peter and Johnson (2009) found only one section where the gradational contact between the Ward Point
Member and overlying Grand Anse Formation was exposed (Hard Ledges Syncline on the western side of the Maringouin Peninsula of New Brunswick). They state that in the type section of the Boss Point Formation "rocks considered correlative with the Ward Point Member are conformably overlain by redbeds of the Little River Formation, the latter of which are tentatively correlated with the Grand Anse Formation of New Brunswick." This statement suggests that they recognize the distinctiveness of the proposed North Reef Member and that it may be laterally equivalent to the upper part of the Ward Point Member. Given the uncertainty in regional correlations, it is also possible that the North Reef Member is laterally equivalent to the lower part of the Grand Anse Formation.

St. Peter and Johnson (2009) demonstrate that members of the Boss Point Formation may be somewhat localized features that can be traceable only for a few kilometres before passing into lateral equivalents. Correlations into New Brunswick are uncertain (see above), as are inland correlations in New Brunswick.

\section{Age}

Palynological study of the Cumberland Group suggests a late Namurian to Langsettian age for the Boss Point Formation (Utting et al. 2010); more detailed dates are not possible given the lack of biostratigraphically useful fossils.

\section{APPENDIX 2 (pages 32-43)}

Measured section of the type section of the Boss Point Formation, Joggins Fossil Cliffs UNESCO World Heritage Site. Metreage in this measured section is designated on the 1:10 000-scale map provided in Fig. 3. 

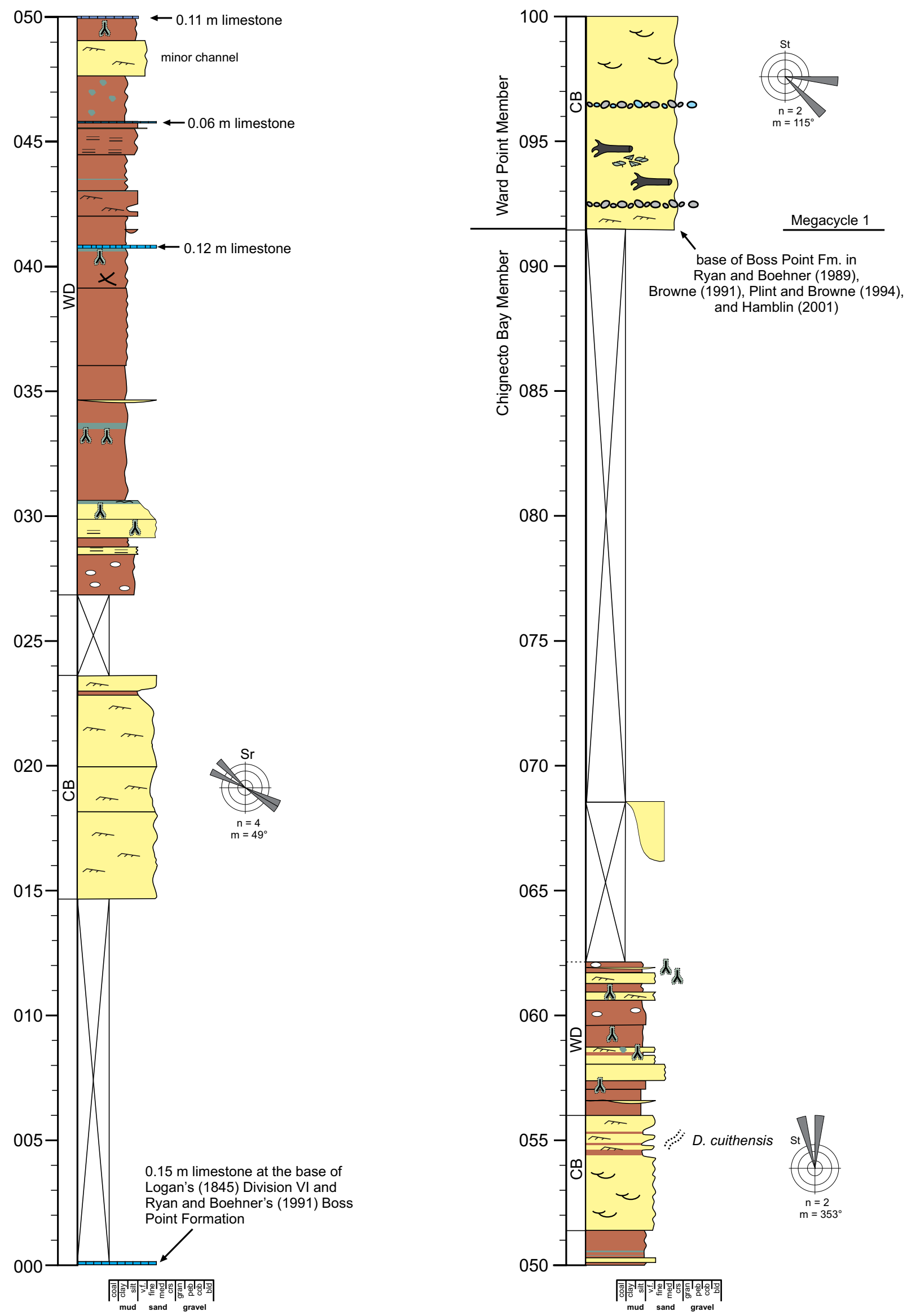

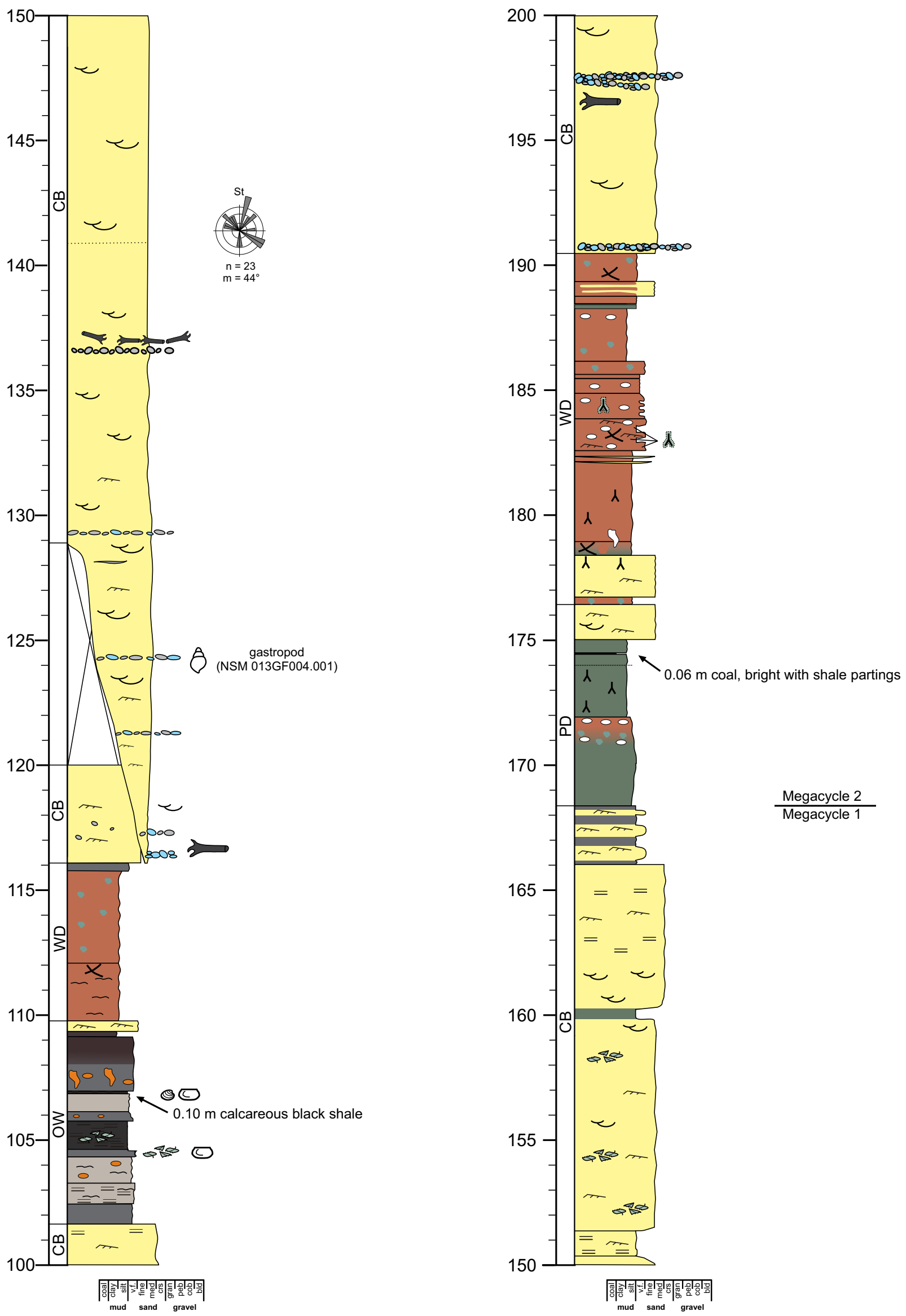

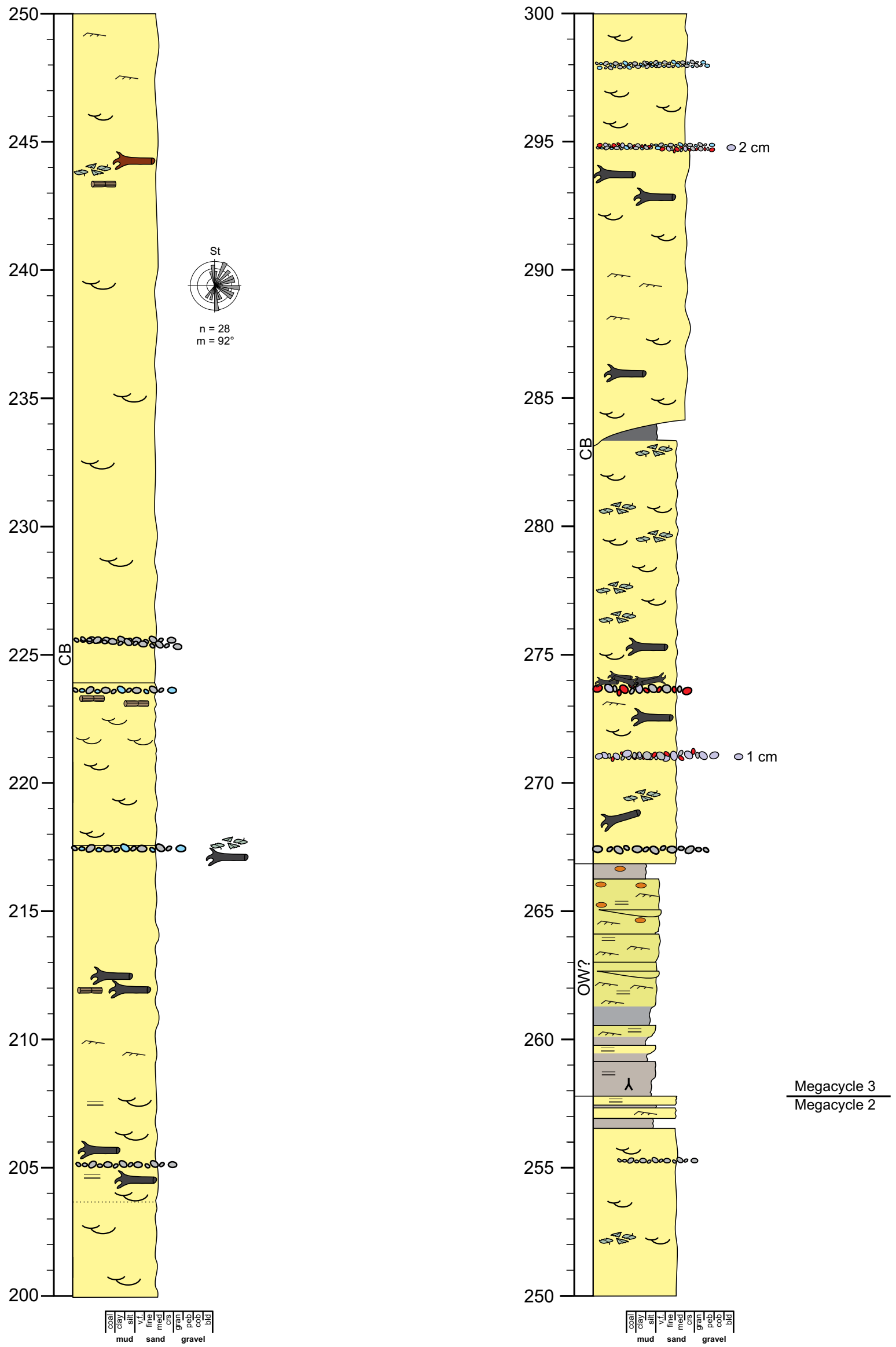

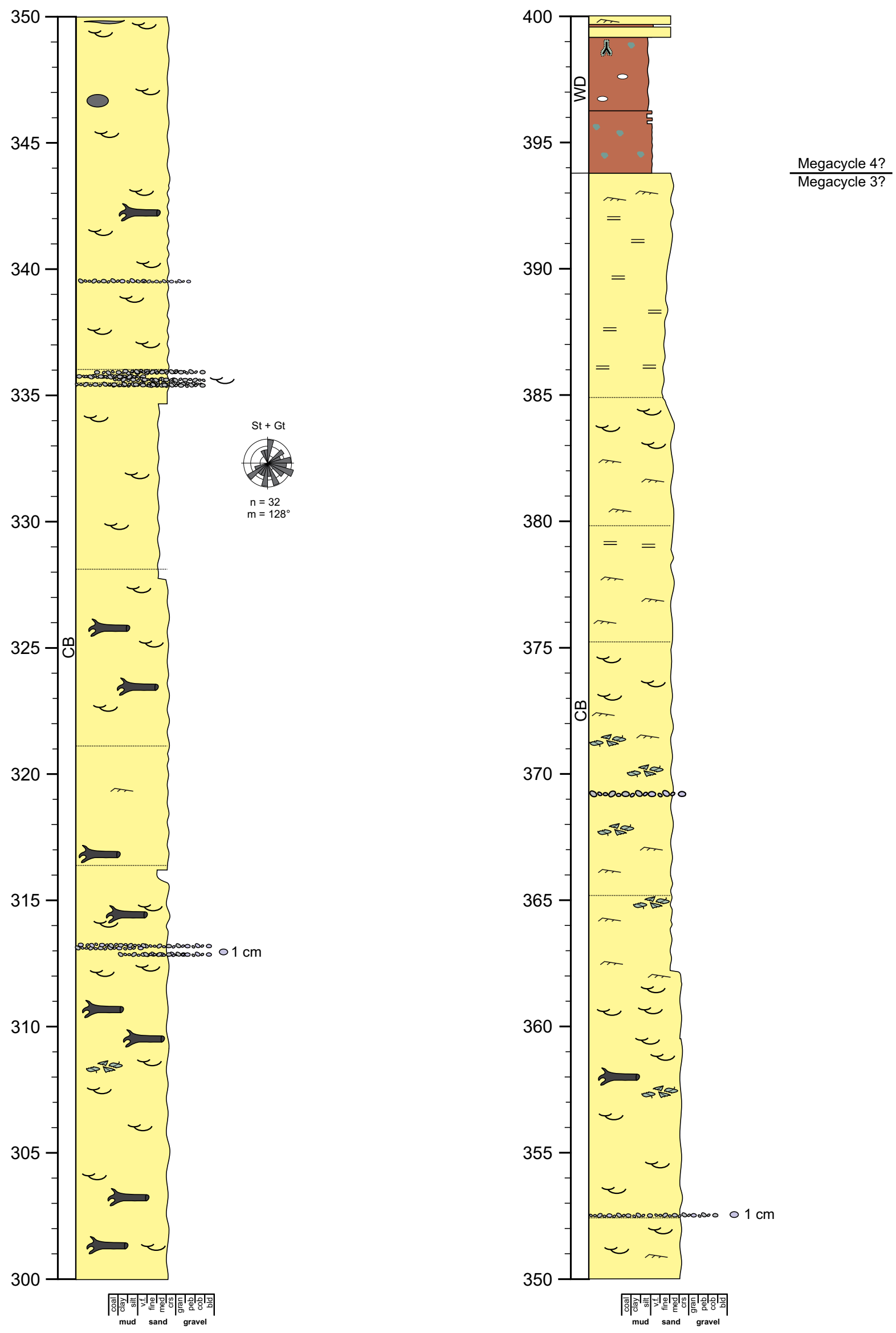

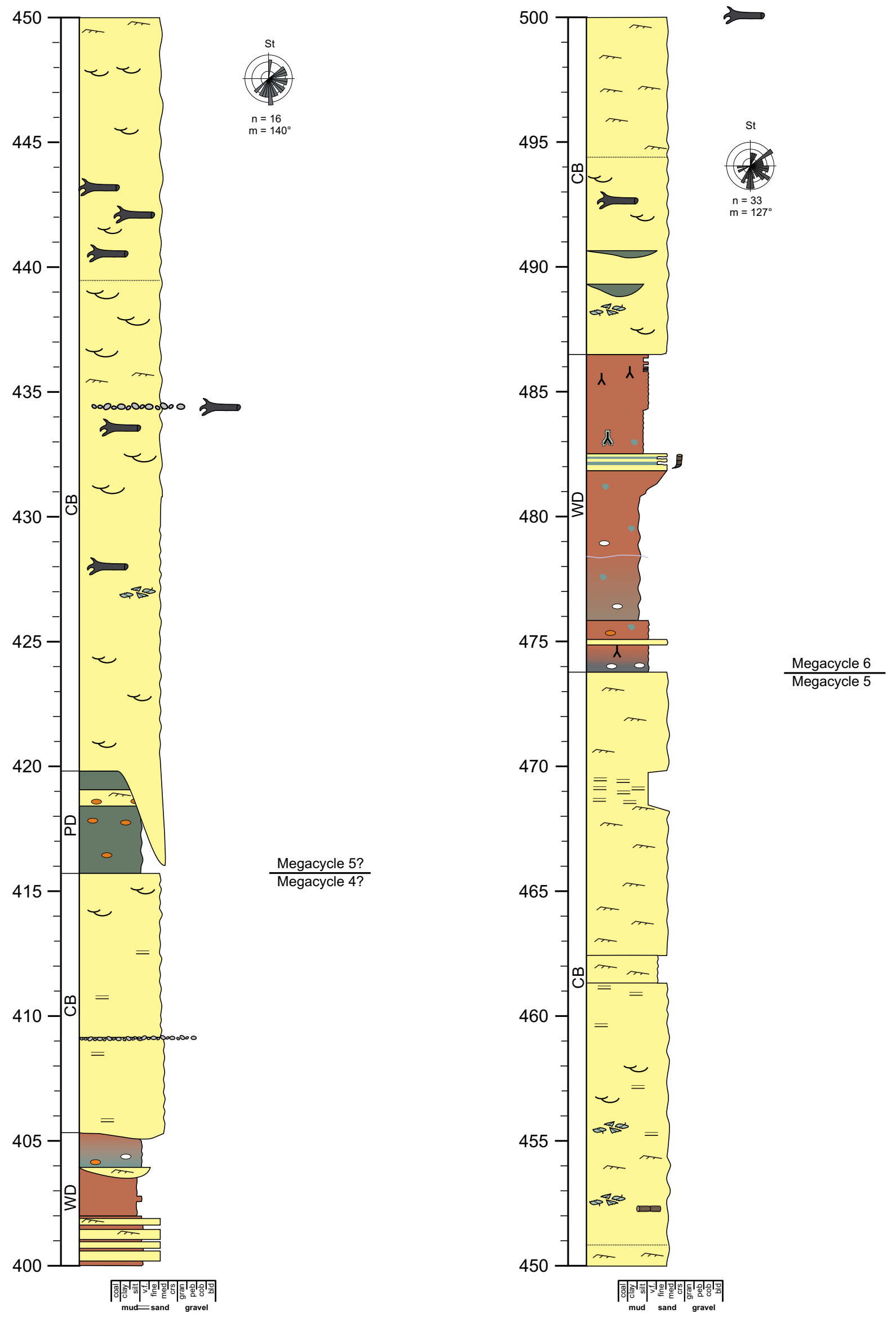

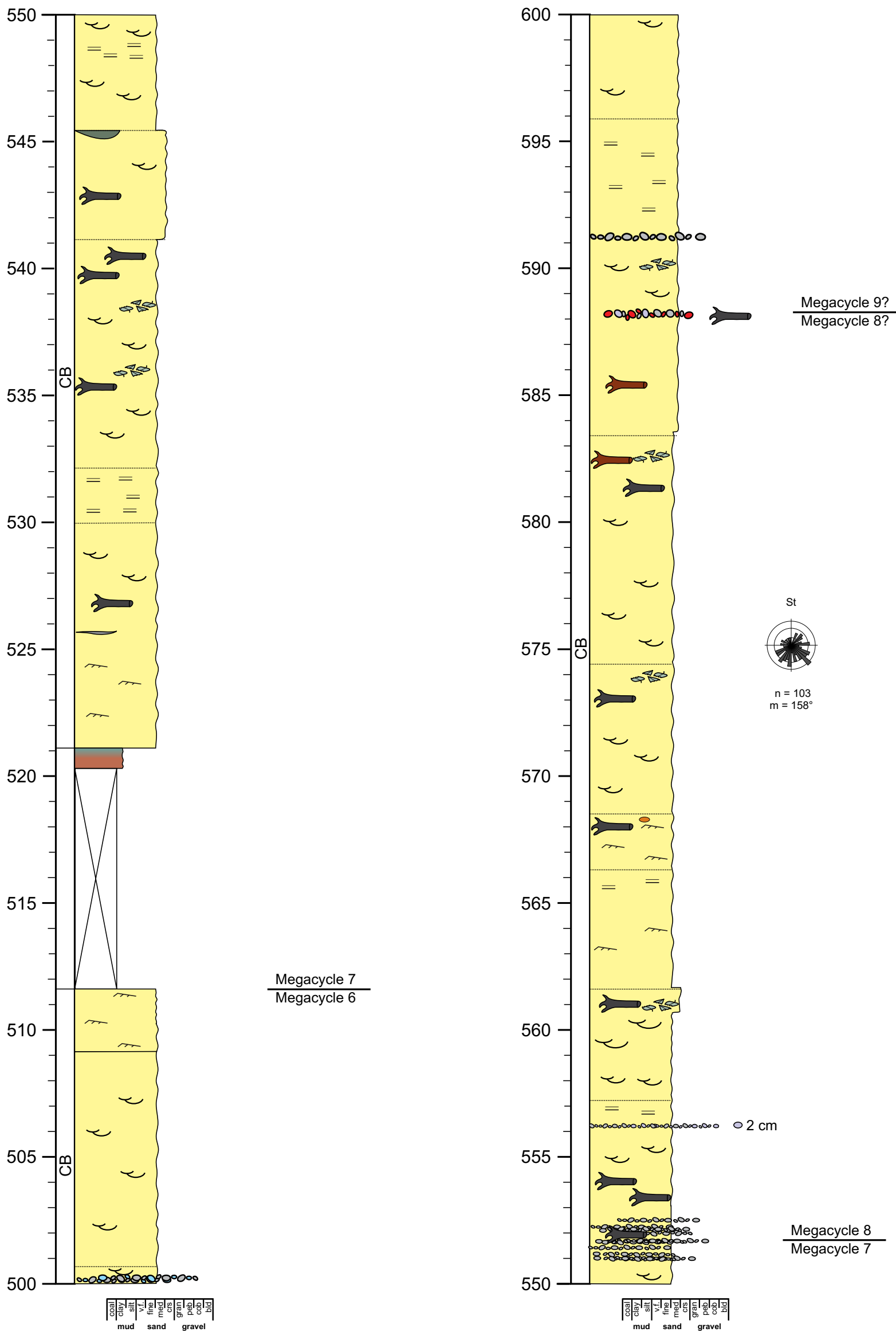

Megacycle 7 Megacycle 6 

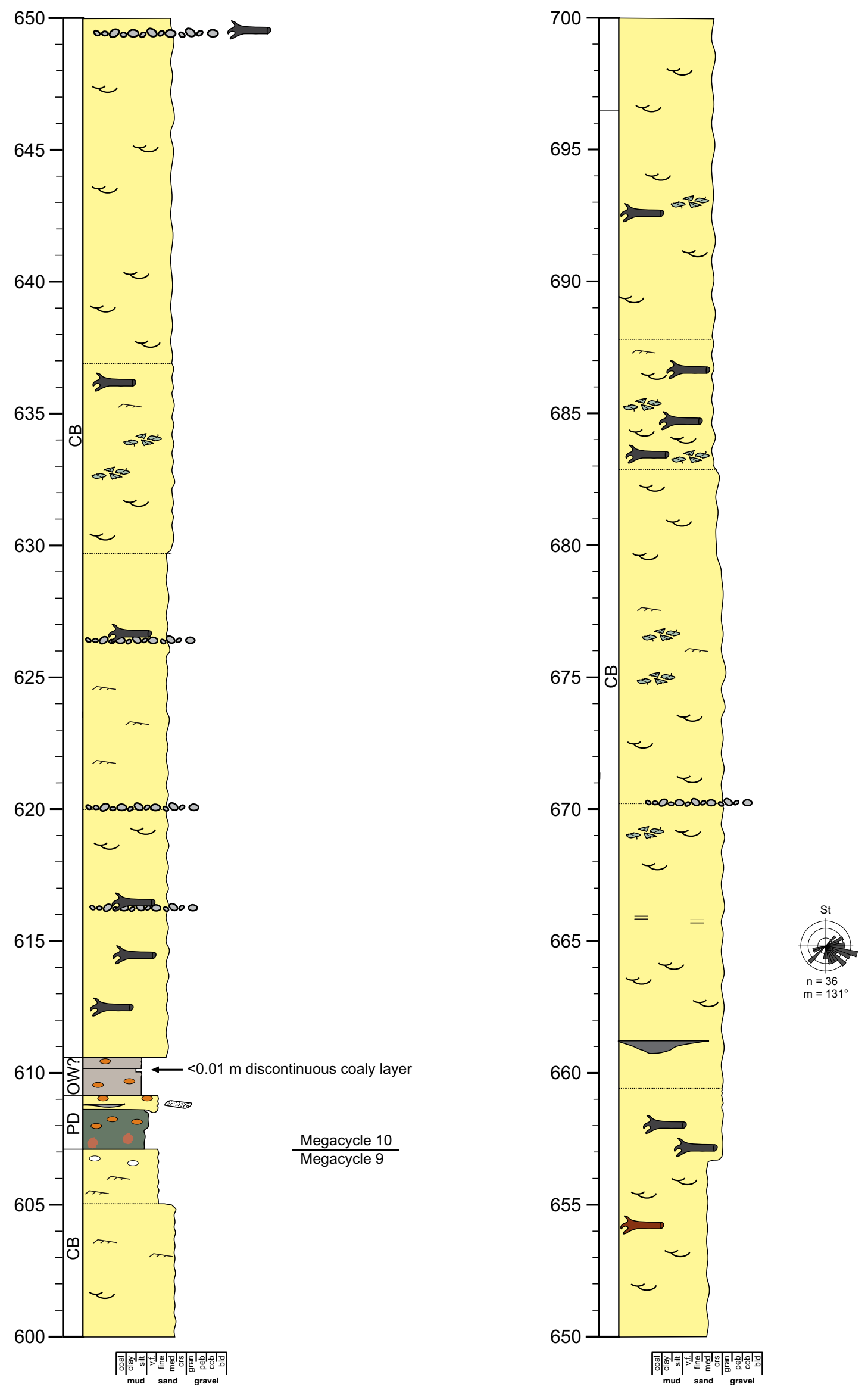

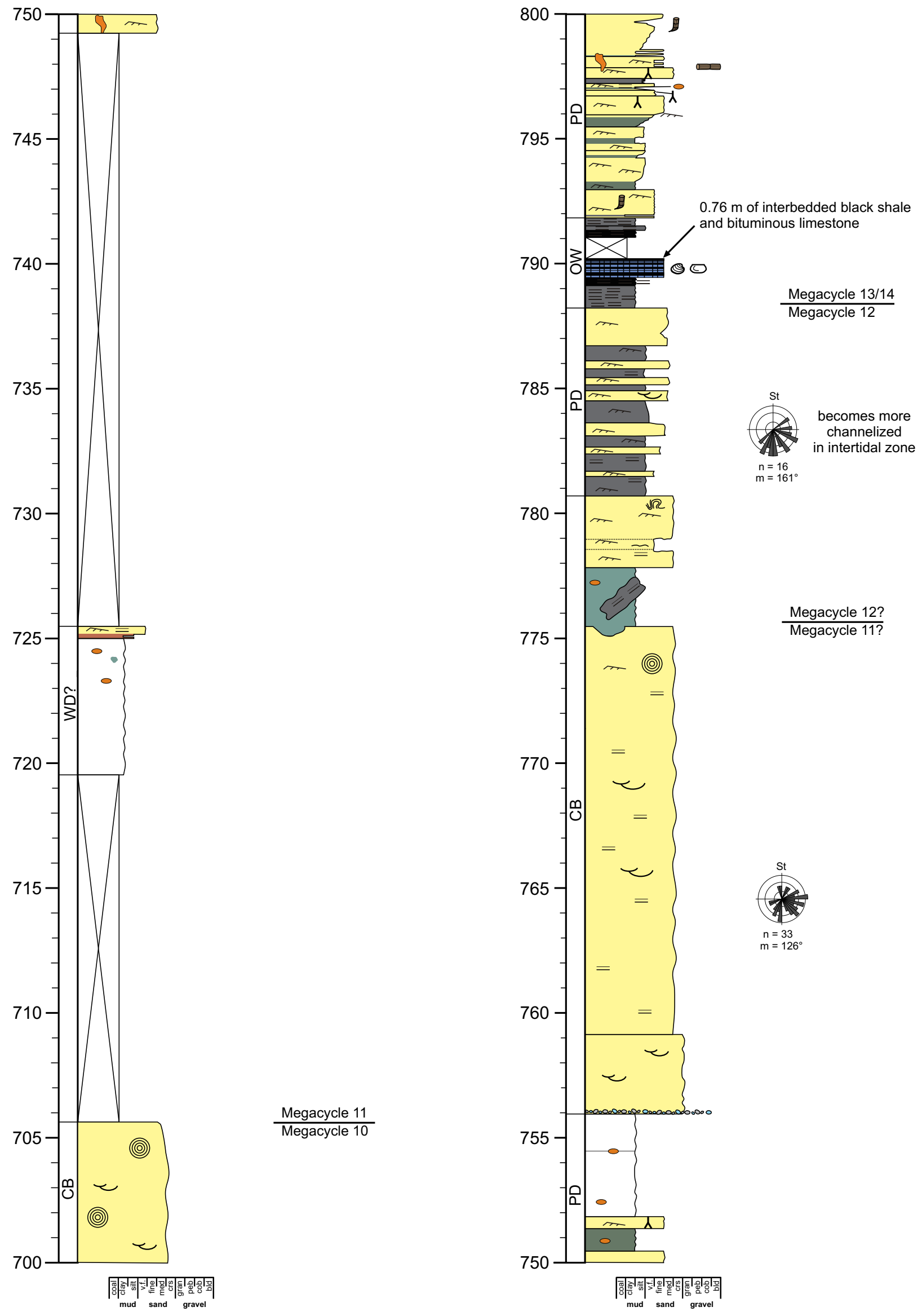

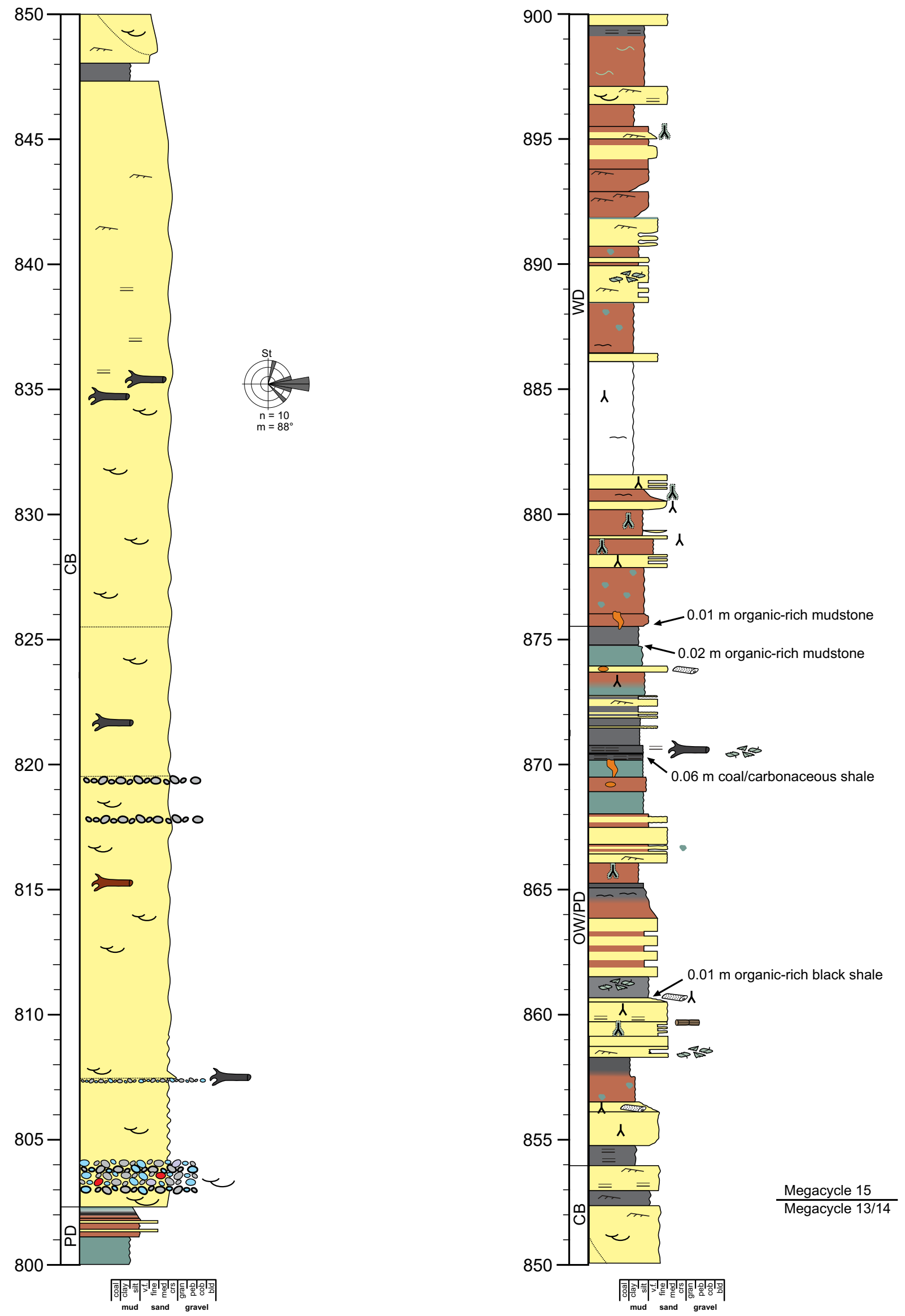

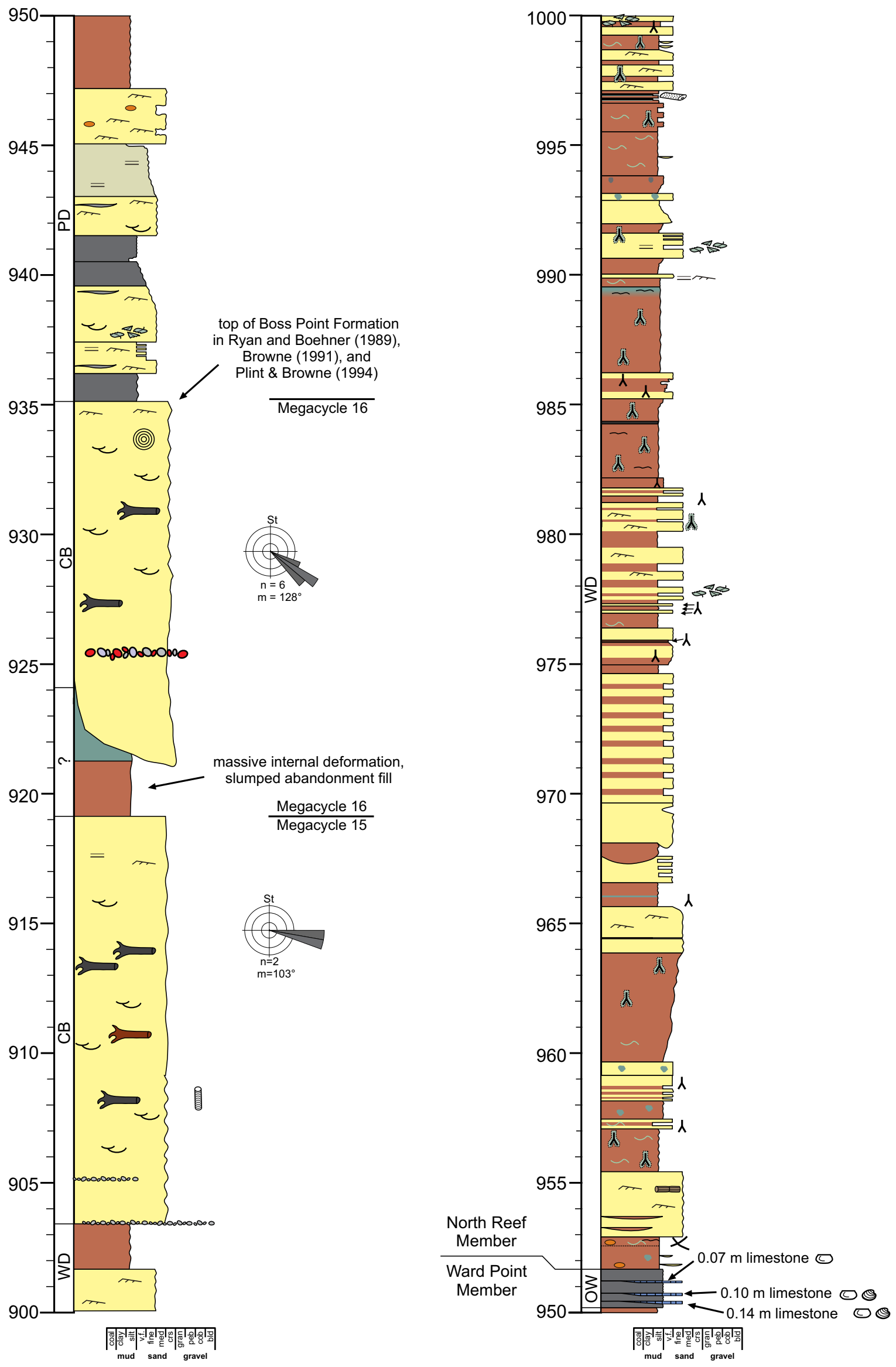

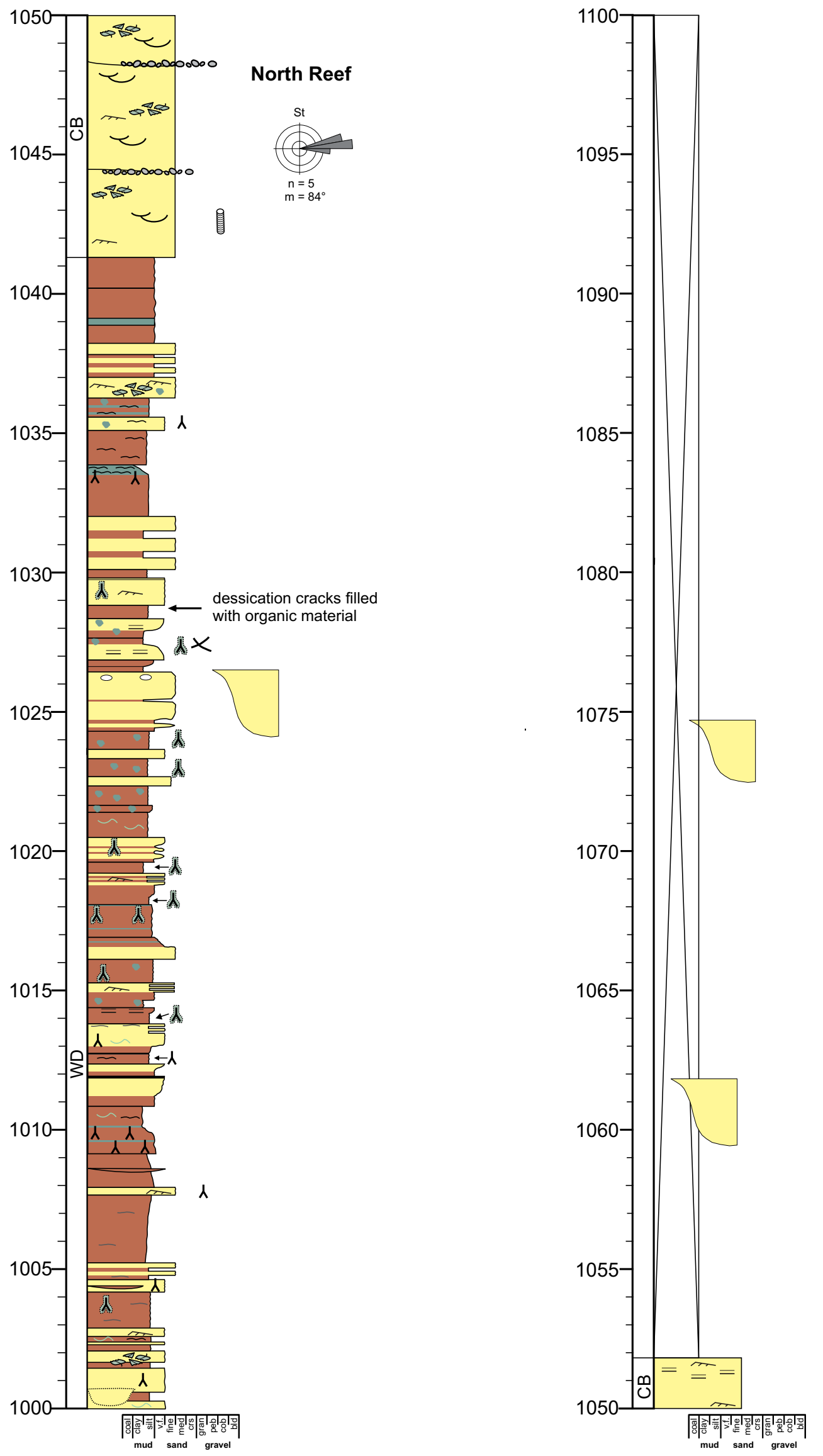


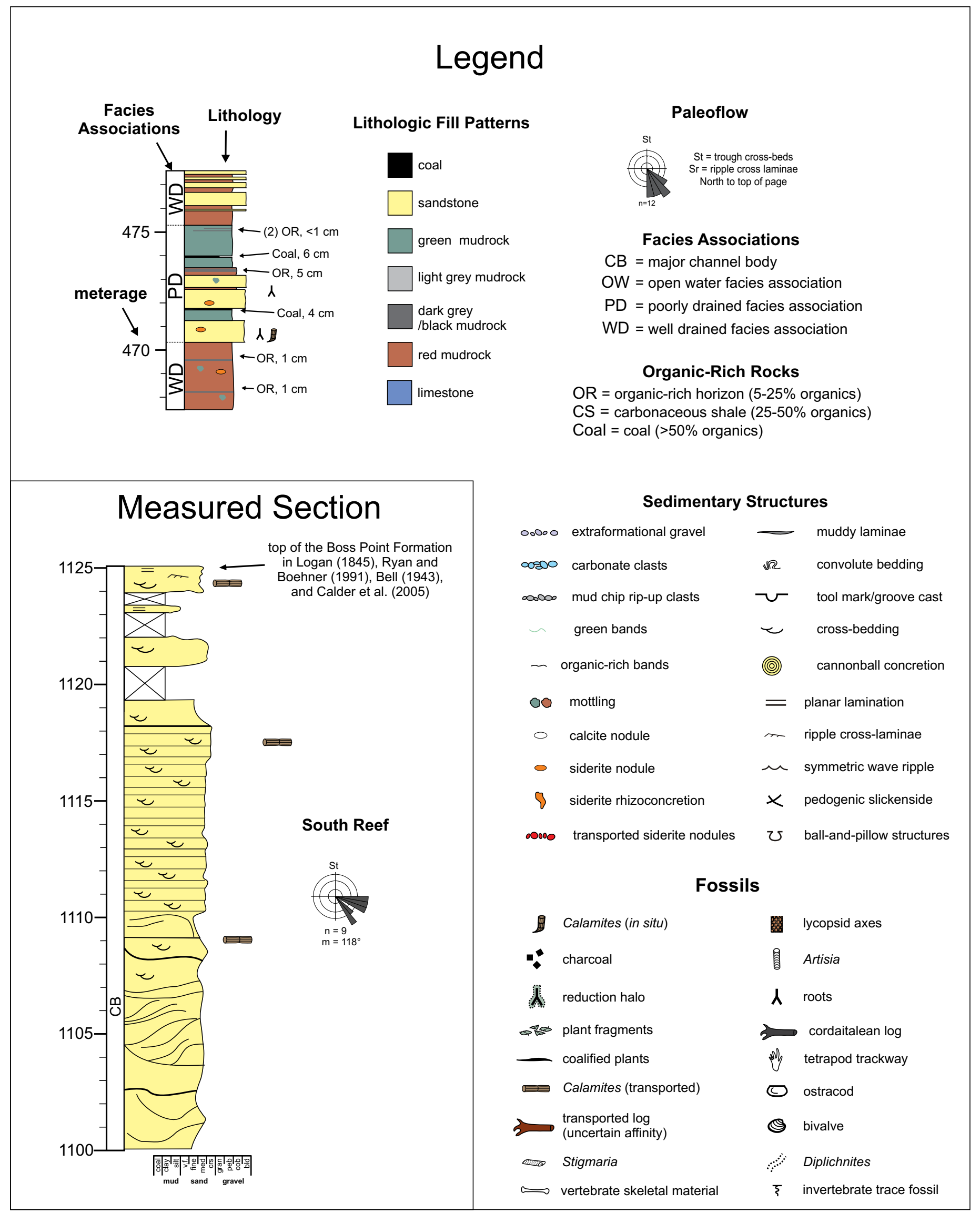

